
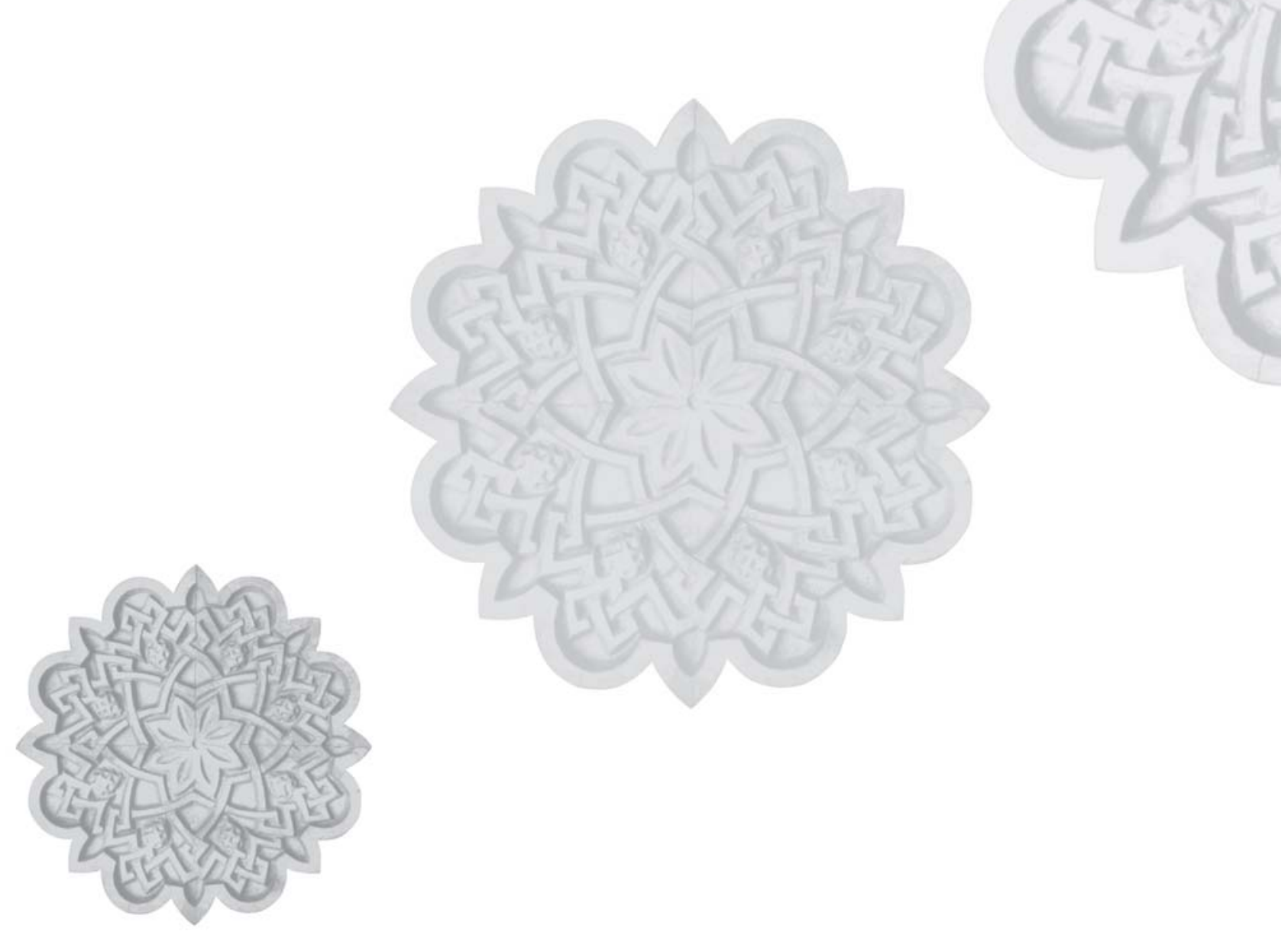


\section{Samuel Pessoa: uma trajetória científica no contexto do sanitarismo campanhista e desenvolvimentista no Brasil}

Samuel Pessoa: a scientific trajectory in the context of public health campaigns and developmentalism in Brazil
Carlos Henrique Assunção Paiva

Historiador, doutor em Saúde Coletiva; pós-doutorando no Instituto de Medicina Social/Uerj cpaiva@coc.fiocruz.br
PAIVA, C. H. A.: Samuel Pessoa: uma trajetória científica no contexto do sanitarismo campanhista e desenvolvimentista no Brasil. História, Ciências, Saúde - Manguinhos, Rio de Janeiro, v. 13, n. 4, p. 795-831, out.-dez. 2006.

Discute a trajetória do médico parasitologista Samuel Pessoa (18981976). Contextualiza sua experiência profissional no quadro das reformas político-administrativas engendradas pelos governos de Getúlio Vargas.

A crescente burocratização de todas as esferas estatais, embora tenha representado desafios adicionais aos gestores das políticas públicas de saúde, como o demonstra a trajetória do médico, não significou, contudo, uma radical esterilização da perspectiva sanitarista campanhista proveniente da elite médica dos anos 20. A trajetória de Pessoa demonstra que essas diferentes 'escolas sanitárias' não se encontravam necessariamente em perspectiva antagônica, ao contrário, ele se revelou não apenas um reconhecido adepto do 'desenvolvimentismo', influenciado por um modelo mais tecnicista no campo da saúde pública, como também não se afastou da arena de discussões dos anos 20 , especialmente com sua vocação para o saneamento do interior do Brasil.

PALAVRAS-CHAVE: Samuel Pessoa; história da saúde pública; burocracia pública.

PAIVA, C. H. A. Samuel Pessoa: a scientific trajectory in the context of public health campaigns and developmentalism in Brazil. História, Ciências, Saúde - Manguinhos, Rio de Janeiro, v. 13, n. 4, p. 795-831, Oct.-Dec. 2006.

The article discusses the professional experience of Samuel Pessoa (1898-1976), parasitologist and physician, within the framework of the Getúlio Vargas government's political and administrative reforms. Pessoa's trajectory shows that growing bureaucratization of all state sectors, presented new challenges to enforcers of public health policies. Nevertheless, this trend did not imply a radical sterilization of the public health campaign approach endorsed by the medical elite in the 1920s. An examination of Pessoa's career reveals how Brazil's various 'sanitary schools' did not necessarily espouse antagonistic views; rather, Pessoa himself proved a recognized proponent of 'developmentalism', influenced by a more technicist public health model, yet did not turn his back on the 1920s discussions, particularly when it came to his interest in sanitary initiatives in rural Brazil.

KEYWORDS: Samuel Pessoa; history of public health; public bureaucracy. 
$\mathrm{O}$ objetivo deste artigo é discutir a trajetória do médico parasitologista Samuel Barnsley Pessoa (1898-1976). Minha proposta é que a atividade desse médico a favor do saneamento e da higiene, no centro de instituições como o Instituto de Higiene de São Paulo, está intimamente relacionada com a ideologia de salvação e construção nacional pela saúde pública, proveniente do movimento sanitário da Primeira República (1889-1930) (ver Castro Santos, 1985; Hochman, 1998; Castro Santos \& Faria, 2003). Pessoa, nascido no final do século XIX, ao longo de sua carreira sem dúvida pareceu fortemente inspirado nos padrões de atuação 'profissional' vigentes e hegemônicos, sobretudo durante as primeiras décadas da República. Assim, creio que a partir da década de 1930, personagens como Pessoa começam a encontrar desafios 'adicionais' para a implementação dos projetos de saneamento e pesquisas científicas. Desafios estes vinculados à instauração, mais ou menos progressiva, de uma burocracia pública no país, a qual em última análise dificultou demasiadamente a rotina de negociação e o acesso dos policy makers ao hall das decisões políticas.

Nesse sentido, assim como ocorreu com outros personagens, Pessoa parecia imbuído de uma forte ideologia, cujos princípios não sintonizavam completamente com os mecanismos burocráticos de ação do Estado que se pretendia instituir, principalmente após a Revolução de 1930. Não que Pessoa tivesse algo efetivamente formulado contra a burocracia no aparelho do Estado, embora com alguma clareza tenha produzido críticas importantes contra o que considerou o excesso de burocratização na saúde pública. O fato é que, para um homem nascido no final do século XIX, o surgimento de uma estrutura administrativa muito mais difusa e complexa, se comparada àquela dos primeiros tempos republicanos, provocou importante descompasso com os novos tempos que surgem nesse prisma, a partir dos anos 30.

Assim, não quero simplesmente discutir as possíveis deficiências operacionais no sistema administrativo que toma vulto a partir das reformas administrativas dos anos 30 . Estou mais intrigado com a possibilidade de perceber os dilemas e problemas no âmbito da gerência pública, a partir da era Vargas, investigando o desencontro estrutural produzido pela construção coletiva de um 'novo tempo', e seu não alinhamento com as trajetórias individuais (padrões de 'comportamento tradicionais'). Em síntese, meu argumento, como discuti em trabalhos anteriores (Paiva, 2003; 2004a; 2004b), é que os anos 30 fazem emergir uma estrutura político-administrativa burocrática, mas não um homem burocrático.

Para desenhar a trajetória de Pessoa, incluindo aí sua atuação profissional, investiguei alguns artigos legados pelo pesquisador à imprensa brasileira, seus trabalhos acadêmicos, bem como os inúmeros depoimentos de seguidores e admiradores de sua obra, gerações 
de pesquisadores que conviveram com o médico paulista e seguiram sua trajetória.

Ao observar a biografia de Pessoa também não pude deixar de me espantar com as imensas dificuldades que o médico viveu na execução dos seus ideais, aqui denominados 'profissionais', ao longo de toda a sua carreira. O espanto é ainda maior quando levamos em conta o profissional de respeito que muito cedo ele se tornou, tanto na qualidade de pesquisador como na de professor. Como explicar o fato de um especialista reconhecido e atuante no então meio científico nacional do pós-1930 ter passado por tantas dificuldades 'profissionais'? A chave não está em uma mudança radical nos ideais de salvação pela saúde pública, vigentes e atuantes na Primeira República, mas exatamente na dificuldade de esses ideais continuarem operando após a Revolução de Outubro. Essa é a minha sugestão de análise.

Assim, não creio que rótulos como sanitarismo campanhista, sanitarismo desenvolvimentista, ou mesmo o denominado modelo Sespiano (proveniente do Serviço Especial de Saúde Pública-Sesp), sejam suficientes para interpretar a ação dos atores sociais daquela época, pois muitos, como Pessoa, não se enquadravam perfeitamente nesses modelos, mais evidentes e bem-acabados às gerações futuras que aos próprios contemporâneos.

\section{A trajetória: o médico-pesquisador}

Samuel Pessoa nasceu em São Paulo, em 31 de maio de 1898, e até 3 de setembro de 1976, data de sua morte, colaborou decisivamente para a fundação de uma importante escola de parasitologia médica do continente sul-americano. É mesmo reconhecido como uma das maiores autoridades na produção de conhecimento sobre os parasitas que atacam as populações do nosso continente, especialmente as que habitavam as imensas áreas de pobreza. Filho de Leonel Pessoa, também médico, e Anna Barnsley Pessoa, imigrante inglesa, estudou no Ginásio Anglo-Brasileiro nos primeiros anos do século XX, e sem dúvida recebeu daquela instituição uma educação sólida e de qualidade.

Em 1916, Pessoa se matricula na Faculdade de Medicina e Cirurgia de São Paulo, recém-fundada (1912). Precisamente em momento bastante fecundo do desenvolvimento da ciência no estado, graças, entre outros aspectos, a certo boom de crescimento econômico produzido pela indústria do café e, mais adiante, à relação internacional que se estabeleceu entre políticos e cientistas com a presença da Fundação Rockefeller no estado, mais incisivamente a partir de 1918. Esse ambiente de prosperidade econômica, aliado à aproximação da Fundação norte-americana ao campo científico paulista, é exatamente o contexto geral definidor do início da 
carreira de Pessoa, quando este contava apenas cerca de vinte anos de idade. ${ }^{1}$

Dois anos depois de matriculado na faculdade, Pessoa passa à atividade de campo em saúde pública, ao trabalhar no posto médico da Associação Cristã de Moços, sob a orientação do professor Henrique Linderberg, no quadro da grave epidemia de gripe espanhola que atingiu não só São Paulo, mas quase todo o país durante o ano de 1918. Em 1920, por conta da ajuda de Samuel Darling, ${ }^{2}$ Pessoa já desfrutava a condição de auxiliar acadêmico do Instituto de Higiene de São Paulo (atualmente Faculdade de Saúde Pública da Universidade de São Paulo). O estudante de medicina se forma no ano de 1922, ao defender a tese "Estudo dos componentes de óleo essencial de chenopodio. Sua aplicação na profilaxia da ancylostomose", ${ }^{3}$ a qual gerou seu primeiro trabalho publicado no Boletim do Institu to de Higiene de São Paulo (n. 13, 1922). Além disso, já em 1921 Pessoa havia sido nomeado interno de Clínica Pediátrica.

Creio que o médico encontrou ali um quadro de possibilidades abertas que era muito peculiar a São Paulo. Isso porque há evidências que apontam o fato de que São Paulo vivia sob um grau de institucionalização da pesquisa científica muito particular, se comparado a outros lugares do país, mesmo a exceção do Rio de Janeiro, onde, como se sabe, instituições como o antigo Instituto Soroterápico de Manguinhos já encerravam uma história marcante no campo da pesquisa científica constituída. Esse desenvolvimento tardio, como considera Castro Santos (1993), acabou por beneficiar os paulistas, pois os libertou de uma série de preconceitos a respeito da bacteriologia e da medicina pasteuriana. ${ }^{4}$

O resultado foi que muito cedo, do ponto de vista da constituição de suas instituições de pesquisa, os paulistas encontraram não só condições econômicas para investir em outros campos, por conta de certa fartura de capitais, mas também um ambiente ideológico favorável a novidades. Além disso, a presença da Fundação Rockefeller no estado, com a introdução de um modelo de produção científica em moldes norte-americanos e europeus, com jornada e dedicação compatíveis ao título de pesquisador, parece ter sido ingrediente importantíssimo para a instalação e o desenvolvimento da pesquisa científica, não só no estado, como em todo o país (Faria, 1994).

O caso da Fundação Rockefeller constitui marco interessante, pois fácil e equivocadamente poderia se considerar que boa parcela das mudanças ocorridas no estado em prol da institucionalização da pesquisa científica - principalmente com a criação da figura do pesquisador, profissional que dedicaria tempo integral aos afazeres da ciência - representasse mera determinação da instituição norteamericana, simplesmente ao impor um modelo de produção alienígena ao ambiente brasileiro. No entanto, se lembrarmos que 
a relação dos Rockefeller com o campo médico brasileiro, segundo o trabalho de Lina Rodrigues de Faria (2002), se deu justamente em 1918, no Distrito Federal e nos estados do Rio de Janeiro, São Paulo, Minas Gerais e Maranhão, veremos a existência de novos ingredientes no meio paulista, os quais, misturados às diretrizes norteamericanas, imprimiram igualmente novo rumo, e conseqüente avanço, ao fazer ciência nacional ${ }^{5}$ (Faria, 2002; Castro Santos \& Faria, 2003).

Nesse sentido, tanto Castro Santos (1987) como Benchimol (1990) e Benchimol \& Teixeira (1993) ressaltam a maneira pragmática pela qual as elites paulistas lidavam, naquele contexto, com a prática científica, o saneamento e a saúde pública. Foi um período de eminente crítica ao bacharelismo, tradicional à República Velha, cuja posse de conhecimento, na visão da época, não vislumbrava uma aplicação direta.

É nesse contexto, bastante geral, que o médico Samuel Pessoa vai se tornar personagem atuante e definidor de rumos na história da saúde pública no nosso país. Pessoa não pode ser percebido como mero reflexo dos acontecimentos apontados. Estava em situação ativa, como muitos outros personagens da época. E é essa posição extremamente atuante no cenário de seu tempo que o fará um definidor dos acontecimentos, um agente histórico com todas as letras.

Assim, no ano de conclusão do curso de medicina, o médico passa à condição de assistente pensionado (resident fellowship) da Fundação Rockefeller para estudos de higiene rural. ${ }^{6}$ Porém, de imediato, recusa convite do diretor da Fundação no Brasil para trabalhar com o Dr. Mark Boyd $d^{7}$ contra a malária na Baixada Fluminense. ${ }^{8}$ Após o término do estágio financiado pela Rockefeller, em 1923, o médico assume o cargo de inspetor sanitário no Serviço Sanitário do Estado de São Paulo, quando se torna médico-chefe de um posto experimental da Inspetoria de Profilaxia Geral do Serviço Sanitário do Estado, localizado em Ubatuba. Lá permaneceu apenas três meses, realizando pesquisas, sendo logo transferido para Caraguatatuba, ainda no litoral norte do estado. É nesse ambiente que Pessoa desenvolve suas primeiras pesquisas sobre verminose, justamente no quadro das profundas transformações na estrutura político-administrativa, promovidas por Geraldo de Paula Souza e pela presença da Fundação Rockefeller no estado.

Durante entrevista concedida, em 1955, ao jornal O Bisturi, Pessoa comenta as influências mais decisivas no início de sua longa trajetória. Todas, segundo ele, responsáveis por seu interesse pela pesquisa científica, sobretudo pela parasitologia. O primeiro nome lembrado é do Wilson Smillie, médico que, segundo Pessoa, 
passava sua férias no nosso vasto hinterland em busca de suas soluções científicas. Ao professor Smillie devo, em grande parte, o gosto que toda a vida mantive por estudos epidemiológicos de campo, das nossas endemias rurais. Os meus primeiros trabalhos foram publicados em colaboração com este pesquisador americano. Não se pejava o mestre em enviar a conhecidas revistas médicas americanas, artigos em conjunto, colocando ao lado do seu nome já afamado, o do modesto estudante de medicina. Não preciso sublinhar o quanto de estímulo tal fato representa para quem inicia sua carreira científica. (O Bisturi, 1955)

Com o Dr. Smillie, proveniente da Universidade Harvard, então professor de higiene da Faculdade de Medicina de São Paulo, o jovem estudante do quinto ano de medicina realizou suas pesquisas sobre verminose entre os escolares do estado de São Paulo. O tema de sua tese de final de curso, bem como a escolha da parasitologia como filão de pesquisa de toda a vida, Pessoa atribui à influência direta e marcante do médico norte-americano. Além de Smillie, o médico chama atenção também para o papel do mineiro Guilherme Bastos Milward, médico e engenheiro formado pela Escola de Minas, seu professor de Química Médica (posterior Química biológica ou Bioquímica)..$^{9}$ A respeito de Milward, Pessoa relata que este foi

um dos mais completos representantes da cultura enciclopédica, aliada a um espírito altamente humano e nacionalista. Ensinava, não só química, como antes de tudo a amar o Brasil. (O Bisturi, 1955)

De acordo com o trabalho de Maria Eliana Labra (1985), no campo da saúde pública, a importação de uma visão técnica, avessa à política, tem a ver com a ação de algo que a autora denominou "conexão sanitária internacional", cujo braço no nosso país foi, segundo ela, a Fundação Rockefeller. Nesse contexto, ainda de acordo com seu ponto de vista, haveria divergência entre os higienistas "tradicionais", mais ligados à higiene rural e os sanitaristas novos, estes, nas palavras da autora, "adeptos da escola norteamericana e ligados à alta burguesia urbana" (1985, p. 397). ${ }^{10}$

A trajetória de Pessoa, contudo, constitui bom exemplo de que essa antítese proposta pela autora é questionável, pois a influência da Fundação Rockefeller sobre os médicos de São Paulo, como já apontam os trabalhos de Castro Santos e Faria, não significou exatamente uma ruptura histórica radical, pois mesmo a opção da Fundação no sentido de operar naquele estado teve relação com certo reconhecimento de que ali se encontrava terreno viável para as reformas propostas, e não impostas. Assim, figuras como Pessoa, em sintonia com o sanitarismo dos anos 20, não só dão 
continuidade ao interesse pelo interior, como também recebem todo um suporte científico e técnico, por parte do pessoal da Fundação; esta, no final das contas, alimentou o que se operava vivamente, pelo menos desde o início do século XX, no âmbito da elite médica brasileira. ${ }^{11}$

Além disso, as influências pessoais de Samuel Pessoa, aqui mencionadas, por si só constituem exemplos de um tempo em que a dimensão técnica não se encontrava inteiramente divorciada, embora muitas vezes o pretendesse, das paixões ideológicas. O motor das intervenções estava justamente calcado em pressupostos de ordem ideológica, embora envolvido sob o verniz do discurso técnico-científico que oferecia alguma orientação de sentido (e não de força) às propostas.

De qualquer modo, não pensemos que esse conteúdo ideológico, aqui tão ressaltado, funcionasse como uma espécie de vara de condão em face dos graves problemas do país. Uma reportagem da revista Realidade de janeiro de 1968 descreve um caso que revela algo das condições de trabalho do médico no litoral paulista, durante o início de sua carreira:

como [Samuel Pessoa] sabia que dificilmente aparecia um médico naquela cidade, levou bastante remédio e, nos intervalos dos exames de fezes, dava receita para todo mundo. A notícia de que havia um doutor na cidade atraiu gente de todas as vilas próximas. A certo momento acabou o remédio, mas o pessoal continuou chegando. Logo correu o rumor de que o médico estava escondendo as pílulas, e daí para a violência foi um passo. $\mathrm{O}$ posto sanitário foi invadido e o jovem pesquisador só conseguiu salvar-se porque um pescador, que se tornara seu amigo, o levou às pressas para Ilha Bela, numa canoa a remo. ("Do que morre o Brasil", 1968).

A despeito de todos os desafios, segundo o doutor Marcelo Osvaldo Alvares Corrêa (ver Pessoa, 1978), do Instituto Adolfo Lutz, os excelentes resultados obtidos por Pessoa na administração do Posto Experimental de Ubatuba valeram ao médico o cargo de Assistente do Instituto de Higiene de São Paulo, o centro de comando, se assim podemos dizer, das mudanças promovidas por Geraldo de Paula Souza, e ainda o cargo de Assistente Interino de Higiene da Faculdade de Medicina, em 1924. Além de servir de principal motivação para que Paula Souza, então diretor do Serviço Sanitário do Estado de São Paulo e homem-chave na relação do estado com a Fundação Rockefeller, criasse os consagrados Centros de Saúde.

Os Centros de Saúde, na visão de muitos sanitaristas, como o próprio Samuel Pessoa, representavam a grande oportunidade de integração da medicina clínica aos fundamentos da saúde pública. 
Nessa integração, acreditava Pessoa, residia uma das melhores oportunidades de beneficiar as populações desassistidas, pelo fato de se aliar ao tratamento, muitas vezes urgente, a educação sanitária, e assim beneficiar duplamente as pessoas consideradas ignorantes a respeito de qualquer princípio de saúde pública já consagrado. Além disso, os Centros de Saúde, que na verdade não eram novos, pois haviam sido concebidos no contexto da Reforma Sanitária da Primeira República, ${ }^{12}$ significaram também ruptura com o velho universo do autoritarismo da prática médica do início do século $\mathrm{XX}$, justamente ao pautar a saúde de todos como um processo de 'sedução' à causa da higiene. Isto é, os Centros de Saúde representaram não só um elemento de continuidade histórica, como lembra Faria (2003), mas também um marco radicalizador das experiências da década de 1920, sobretudo no estado de São Paulo, região brasileira em que esse modelo mais progrediu e se difundiu como bandeira sanitária. Nas palavras de Pessoa, ao avaliar em retrospectiva o trabalho dos Centros em meados dos anos 40:

Em nosso estado, entretanto, divorciaram-se completamente as atividades hospitalares das de saúde pública. É raro, entre os municípios, contando com suposta assistência médica hospitalar, existir algum que não possua completamente divorciado do centro de saúde, ou do Posto de Assistência Médica Sanitária, o hospital geral ou a Santa Casa, dotado de precário laboratório, isolado arremedo do serviço de puericultura, sem nenhum laço de afinidade, nem mesmo oficialmente, com os serviços de higiene locais. ("Os hospitais e a saúde pública", 1945)

No contexto da chamada verticalização dos serviços médicos no país, o 'divórcio', a que o médico se refere, dizia respeito à falta de cooperação institucional entre o hospital e o centro de saúde, pois, em sua visão, "ambos têm as mesmas oportunidades para educar o povo em questão de saúde, através da enfermeira visitadora ou educadora, entrar um pouco mais amplamente em todos os meios sociais" (ibidem). Essa ausência de cooperação, porém, tinha repercussões importantes, pois imprimia ao tratamento, ou à saúde de maneira geral, uma dimensão puramente biológica, ao desconsiderar o modo de vida do sujeito, bem como de sua comunidade. A doença era eminentemente algo circunscrito ao corpo do doente, apesar de todo o conhecimento já produzido e difundido que afirmava o contrário. ${ }^{13}$

Nesse mesmo quadro de discussão, Pessoa faz referência à complexidade burocrática e administrativa que adquiriu o sistema público, a qual não favorecia um grau de interação considerado satisfatório - do ponto de vista do tratamento e da assistência das populações -, naquelas unidades responsáveis pela saúde. Na visão do médico, havia um fosso político-administrativo, que dividia, 
de um lado, as preocupações e ações em relação ao 'ambiente', de um ponto de vista mais amplo (a visão ecológica); de outro, a visão 'hospitalar', já mencionada, responsável pelo tratamento dos males do corpo físico (organismo biológico). Desse modo, a interação desejada não era operada, em muitos sentidos, desde o ponto de vista epidemiológico até o estritamente administrativo, em razão da predominância de uma visão extremamente setorial a respeito dos problemas de saúde e das práticas assistenciais.

Essa visão mais burocratizada do funcionamento da saúde pública já implica, em alguma medida, importante distanciamento com relação à dinâmica de operação da saúde pública, durante as primeiras décadas do século XX. Ainda que a proposta dos Centros de Saúde não fosse suplantada pela verticalização e especialização dos serviços, creio que a generalização de um modelo vertical no campo da saúde pública, isto é, a criação de serviços de combate a doenças específicas, como febre amarela, malária e lepra, que desembocarão nos serviços nacionais a partir da década de 1940, tem relação com uma visão da saúde pública, por parte de muitos dos gestores governamentais, bastante pragmática; tratava-se de simples controle das epidemias e endemias consideradas mais importantes, não existindo aí, estruturalmente envolvidos, elementos ideológicos que transformassem a atividade médica em ato simbólico de construção da nacionalidade.

Isso porque é fundamental perceber que, nesse contexto, saúde e educação tinham conotação relativamente distinta da que adotamos hoje. A força desses discursos e práticas tem muito a ver com a forma pela qual a realidade humana foi pensada. Em termos históricos, o curto período de pouco mais de oitenta ou setenta anos que nos separa dos sanitaristas e educadores das décadas de 1920 e 1930 demarca novo lugar da saúde e da educação em nossa sociedade. Durante esse período, pelo menos dois fenômenos importantes aconteceram nesse sentido. O primeiro é a crescente burocratização do Estado, que interfere agressivamente nos projetos e nas políticas públicas do país. Gradualmente, os processos de decisão vão ficando cada vez mais complexos e exigentes, o que dificulta a ação, carregada de sentido ideológico, dos pensadores (sanitaristas-educadores) acerca dos problemas do Brasil. Outro ponto é o fato de ter sido facultado um 'lugar' para a saúde e para a educação, com a crescente especialização e separação das áreas de saber, que toma vulto no correr do século XX e já se encontra bastante visível na segunda metade do século.

Assim, caberia aos especialistas encarregarem-se de suas fatias de saber. Cada um, às vezes de maneira equivocadamente autônoma, passou a fechar-se dentro de um casulo de conhecimento, compreendendo o mundo sob a ótica de sua célula. Não que a especialização representasse por si só um atraso no âmbito da produção 
de conhecimento; ao contrário, permitiu a produção de trabalhos com uma riqueza de detalhes jamais experimentada. Entretanto, segundo a visão de médicos como Samuel Pessoa, muitos dos problemas humanos, incluídos aí os sanitários e os ambientais, não poderiam ser compreendidos em sua plenitude, sem a necessária visão do todo. Assim, de acordo com o autor, em seus Ensaios médico-sociais:

Devemos considerar, também, que a análise detalhada dos vários complexos patogênicos nos traria melhores conhecimentos da dinâmica das doenças, e assim facilitaria os meios de combatêlas no âmbito da saúde pública. (1978, p. 88)

De alguma maneira, isso tudo tem sintonia com os modernos princípios da administração pública que se pretendia instituir, sob a influência de pensadores norte-americanos, sobretudo a partir dos anos 30 até 50. É a 'ciência da administração', que tinha, por sua vez, seus fundamentos epistemológicos muito vinculados a uma visão do ser humano como criatura não-reativa, fechada em si mesma, a qual, portanto, deveria ser 'domesticada' para fins de rendimento no trabalho. ${ }^{14}$ Dessa forma, os princípios da administração pública, vigentes, sobretudo a partir das reformas administrativas dos anos 30, estiveram em gradual e marcante sintonia com a compreensão de fenômenos sociais, hoje considerados mais complexos, como processos causais que explicam o desenvolvimento das moléstias nos seres humanos. O que realmente ocorre é a instituição de um modelo de assistência, segundo Pessoa, assentado em bases equivocadas, visto que há, do ponto de vista médico, radical separação entre a assistência e o papel atribuído ao hospital (como o locus da medicina clínica) em relação aos centros de saúde (as unidades de saúde pública stricto sensu). O médico considerou que a sensível separação técnica e administrativa entre os serviços de saúde em alguma medida tornava mais complexas as decisões e a atuação dos profissionais no setor, pois a cada problema sanitário caberia um profissional responsável, lotado em alguma unidade do estado, a qual deveria, por sua vez, dar conta do mal, sem a desejada interação com outras arenas institucionais. Esse é o contexto das reformas administrativas e do fortalecimento da via da especialização burocrática, levantados como bandeira, na década de 1920, por muitos intelectuais especialmente ligados à saúde. Bandeira essa mais tarde reafirmada pela Aliança Liberal, que arregimentou a derrocada do período oligárquico, mas levada adiante a partir das gestões presidenciais que se seguem aos anos 30, sobretudo com Getúlio Vargas. Assim, no final das contas, Pessoa, entusiasta das medidas elaboradas por Paula Souza, conclui que: 
Em grande parte, a falha que se nota para conseguirmos maior progresso da higiene nas nossas zonas rurais é a conseqüência de querer-se contar exclusivamente ao Posto de Higiene ou Centro de Saúde a luta contra as moléstias predominantes nestas zonas.

A sociedade não se organiza, não se congrega e nem há o auxílio econômico de quem pode dar, para que se constituam fundações auxiliares destinadas a preencher as lacunas inevitáveis dos serviços oficiais ...

De outro lado, devemos nos capacitar que o problema da melhoria da higiene das zonas rurais constitui uma fase do problema geral da educação. (Revista de Medicina, v. 25, n. 8, p. 9-20, jan. 1941, citado em Pessoa, 1978, p. 248)

É nesse ambiente, e na condição de Assistente do Instituto de Higiene, que Pessoa organiza a Seção de Parasitologia aplicada à higiene, já pertencendo oficialmente aos quadros do Instituto. Como sugere Luiz Rey (2001), até pelo menos o final do século XIX, a parasitologia era mais um ramo da zoologia e menos uma disciplina ligada à área médica. Na década de 1930, ficou clara a importância da disciplina como saber médico, com a introdução do Anopheles gambiae no litoral nordestino, em conseqüência da chegada aos portos nacionais dos modernos e rápidos navios que partiam dos portos africanos. Aos poucos, o vetor foi tomando os vales dos rios Açu, Apodi e Jaguaribe, e por volta de 1938 ocorreu grave surto de malária na região. Nessa ocasião, não só é criado o Serviço de Malária do Nordeste, em 1939, a fim de controlar a expansão da malária nas regiões Norte e Nordeste do país, com a ajuda do pessoal da Rockefeller, como também fica patente a importância da produção de saber sobre esse problema.

Assim, segundo o médico Amílcar Vianna Martins, Pessoa foi o grande reformador do ensino e da pesquisa em parasitologia no nosso país, ao representar o desenvolvimento desse campo, ressaltando justamente o exemplo brasileiro que, nas palavras do médico

veio mostrar que as doenças parasitárias no Brasil não eram meras curiosidades nosológicas, que incidiam em alguns indivíduos sem importância residentes em regiões economicamente não importantes, distantes dos centros civilizados. (Pessoa, 1978 , p. 32) ${ }^{15}$

Nesse sentido, a trajetória de Samuel Pessoa se confunde com a própria criação de uma tradição de conhecimento na área da parasitologia. O médico não só produziu conhecimento, em seu sentido universal, mas também contribuiu para a criação de uma área de conhecimento genuinamente nacional, ligada aos problemas sociais que o país atravessava e enfrentava. Seus trabalhos 
sobre as condições sanitárias das populações nordestinas foram de vital importância, segundo Luiz Hildebrando Pereira da Silva (2001, p. 10), para a evolução do Serviço Nacional de Malária, posteriormente, Departamento Nacional de Endemias Rurais - DENERu. ${ }^{16}$

Após o período de um ano (1927-1928) de cursos e visitas a países europeus, ${ }^{17}$ onde conheceu os serviços antimaláricos lá instalados, o médico retorna ao Brasil e é aprovado, em 1931, no concurso para professor catedrático de Parasitologia da Faculdade de Medicina, ${ }^{18}$ onde formaria, como já disse, importante escola de pesquisadores parasitologistas. Depoimento de Luiz Rey, do Departamento de Helmintologia da Fundação Oswaldo Cruz, assinala a importância de Samuel Pessoa como criador de uma escola de parasitologia no país; segundo Rey, Pessoa "me propôs trabalhar como seu assistente. Foi como me casei com a parasitologia" (2001, p. 4). Assim Samuel Pessoa é encarado como uma espécie de marco zero na institucionalização da parasitologia no Brasil, com seu trabalho na Faculdade de Medicina, onde permaneceu até 1956, quando se aposentou aos 58 anos de idade.

No correr dos anos 30, o Estado iniciou certo processo de expropriação de poder político das oligarquias regionais, em prol de uma estrutura burocrática relativamente autônoma. Em certo sentido, esse processo ganha tom próprio e não-linear no estado de São Paulo, onde diversos segmentos das elites locais resistiram à estrutura de poder do estado getulista. Até então, as oligarquias locais possuíam certas condições políticas, tanto regionais como nacionais, para manter as discussões e decisões substancialmente dentro das fronteiras do próprio estado, o que, de um lado, muito favoreceu a aplicação das políticas de saúde pública na região (Castro Santos, 1993; Hochman, 1998).

Isso porque as elites paulistas, historicamente, desenvolveram nessa matéria uma relação política extremamente tensa com relação ao governo central. Estava em jogo uma sutil fronteira entre a promulgada autonomia concedida pelo governo federal, base do federalismo da Carta de 1891, e a necessidade, marca dos novos tempos, de o governo federal intervir em setores estratégicos, sobretudo do ponto de vista da própria elite paulista, que muito freqüentemente se beneficiava em vários campos, desde o campo econômico stricto sensu, com a política do café (Reis, 1991), até também a socialização dos custos das epidemias e endemias que atingiam o país (Hochman, 1998). Assim, a emergência do Estado getulista significou, nesse sentido, um desafio à continuidade das políticas públicas no estado de São Paulo, pois eram, a autonomia das elites e o controle da máquina pública, ingredientes fundamentais para fazer do executivo estadual um organismo ativo no campo da saúde pública. Autonomia local, como sabemos, questionada pelos revolucionários, muitos dos quais provenientes do 
tenentismo. Desse modo, a centralização e a alta burocratização vieram - para surpresa daqueles que as encaravam como ingredientes de um Estado moderno e eficiente -, para perturbar e aniquilar o status quo que fazia funcionar certa burocracia pública local, fundada em princípios aristocráticos, bem ou mal, responsáveis pelas políticas de saúde pública no estado, pelas campanhas sanitárias e vacinações.

Todas as transformações ocorridas no âmbito da gerência do governo no pós-1930, particularmente agressivas em São Paulo, sem dúvida provocaram, nesse sentido, problemas na execução dos serviços públicos vinculados aos executivos nos níveis estaduais e federal, como já mencionara Samuel Pessoa. A ordem legal e política que sustentava a execução das políticas públicas é seriamente abalada, provocando grave crise no campo da saúde pública, do ponto de vista dos antigos executores. As oligarquias paulistas, por exemplo, que sustentavam a execução das políticas públicas no estado desde o final do século XIX, perdem de imediato muito de sua legitimidade política com a Revolução de 1930. Agora, toda realização governamental, estadual e municipal dependia de um arranjo político demasiadamente mais complexo, se comparado ao período anterior, marcado, sobretudo pelo consenso desenrolado dentro do Partido Republicano Paulista - PRP.

Não é difícil supor que esse abalo não seja perceptível aos olhos de quem estuda ou observa a animada rotina de criação de órgãos e instituições públicas. O crescimento, aos saltos, de uma estrutura burocrática, como a que deu corpo ao próprio ministério, pode trazer consigo a ilusão de crescente preocupação por parte do Estado com relação aos problemas da saúde pública. ${ }^{19}$ Um salto de qualidade, diria um estudioso do desenvolvimento institucional no país. Isso tudo, é claro, se nos esquecermos de alguns daqueles que interagiram com toda essa orgulhosa máquina. Sem eles, com toda certeza, a máquina burocrática não operaria, e simplesmente por isso suas presenças não podem ser ignoradas em forma e conteúdo, sob o risco de construirmos uma rotina na qual os indivíduos figuram como epifenômenos de uma estrutura, seja esta qual for. Uma história sem pessoas.

Penso em um quadro bastante interativo, tanto do ponto de vista da relação entre indivíduo e sociedade, como dos acontecimentos entre si. Desse modo, estimo que a discussão acerca da trajetória de qualquer personagem não seja recomendável, sem que, no mínimo, se possa levar em conta uma seleção de fatos considerados importantes para o quadro de análise. No caso de Pessoa, temos de considerar os fatos relativos a dois contextos gerais, relativamente distintos: (1) o primeiro refere-se ao início do século $X X$, quando as atividades dos médicos ainda estavam profundamente marcadas pelos debates provenientes do século anterior, principal- 
mente em torno da necessidade de centralização das instituições do Estado, o que marcaria a presença de um governo forte nos assuntos públicos, rumo à formação de uma nação moderna e civilizada. Em São Paulo, segundo a literatura (Castro Santos, 1993; Hochman, 1998), havia um aparato burocrático eficiente, mas perfeitamente controlado no âmbito local, diante dos consensos políticos estabelecidos dentro do Partido Republicano.

No entanto, (2) a trajetória profissional de Samuel Pessoa, embora iniciada no correr da República Velha, desenrolou-se basicamente dentro do quadro social do Brasil após Vargas (contexto 2), mesmo com relação a certos aspectos restritos ao mundo da ciência, o que implicou o surgimento de novo vocabulário, que não recusa a importância da dimensão política, mas ao contrário, somase à dimensão técnica e acadêmica da produção em ciência, de acordo com moldes estrangeiros em processo de absorção.

Nesse ponto de vista, a dimensão política dos primeiros tempos dos anos 30 é decisiva para os rumos da saúde pública e dos sanitaristas. O chamado Código dos Interventores, instituído em 1931, estabeleceu nova relação entre o poder central e os estados, ao limitar a ação dos governos estaduais. No decorrer do período, contudo, viu-se que o governo central, representado nos estados pela figura do tenente, não tinha a intenção de realizar transformações sociais importantes, o que o levou a certo entendimento com as oligarquias da região. No entanto, as profundas alterações promovidas na rotina de funcionamento do estado, com a burocratização e a aguda centralização, bem como suas conseqüências políticas e sociais, promoveram muitas vezes certa pane não exatamente na elaboração ou criação, mas justamente na execução das políticas públicas, pois os parâmetros de decisão gradualmente se alteraram na guinada do contex to 1 para o contexto 2, que marca justamente o início da trajetória de Pessoa. Em São Paulo, particularmente, certa estabilidade política só chega com o período constitucional. Após 1934, se estabelece não o antigo equilíbrio político, mas uma forma em que as velhas oligarquias regionais ainda tinham voz. Do ponto de vista da execução das políticas públicas, o problema residia na nova forma de relacionamento que emerge, nos anos 30, entre o aparelho do Estado e atores sociais (formados essencialmente no contexto 1). Paradoxalmente, é no plano burocrático, pretensamente impessoal, técnico e racional, que as políticas públicas de saúde não encontraram terreno fértil de atuação e proliferação. Não exatamente, como já discuti em trabalho anterior (Paiva, 2003), por conta do conteúdo das reformas burocráticas em si, mas em virtude da relação que essa estrutura estabeleceu com os atores sociais vinculados direta ou indiretamente ao setor da saúde, em um ambiente com características muito particulares, se comparadas às realidades norte-americana e européia. Como já mencionei, surge um 
desencontro fatal a todo o empreendimento de construção nacional pela saúde pública, cuja ideologia nacionalista sofre gradual esvaziamento e jamais é retomada com grau e conteúdo iguais nos períodos seguintes.

Com uma estrutura capitalista bastante desenvolvida, se comparada a outros estados da Federação, é de supor que o estado de São Paulo, geopoliticamente falando, tenha experimentado um processo de construção do aparelho do Estado relativamente prévio ao restante do país. A vasta literatura sobre o tema mostra o quanto esse estado se encontrava na dianteira do processo de modernização e desenvolvimento social (Castro Santos, 1993; Hochman, 1998; Lessa, 1999; Fausto, 2000, entre outros). Nessa vanguarda do nationbuilding brasileiro, nota-se desde cedo a formação de nova categoria de 'políticos profissionais', no sentido atribuído por Max Weber (1970). Segundo este, houve tempo em que a atividade política era executada pelos indivíduos, de maneira secundária, nas ocasiões em que se fazia ou se considerava necessária. Nos outros momentos, o indivíduo poderia se dar ao luxo de não se portar exatamente como um 'sujeito político', mas ser - o que é fundamental - potencialmente um político, mais ou menos capaz de participar dos fóruns de decisão política.

Com o surgimento do Estado moderno, dá-se o oposto. Aqui, há uma categoria de indivíduos que vivem 'para' a política. A política se transforma, na concepção de Weber (1970, p. 64-5), em finalidade da vida, pois o seu exercício permite alguma satisfação psicológica pessoal, simplesmente com o gozo do poder ou quando se coloca o indivíduo a serviço de uma causa ou uma ideologia. Aqui, há a idéia de que a política possui regras de funcionamento mais ou menos próprias, independentemente, mais uma vez, do conhecimento técnico e científico, como também de atributos congênitos, como os raciais.

Desse modo, ao se considerar a existência de uma arena própria para a rotina política, imediatamente é forjado o outro lado da moeda, isto é, uma arena em que o homo politicus seja a priori rejeitado. É justamente o que ocorre, pelo menos no plano teórico-discursivo, com a arena das coisas burocráticas que, segundo alguns pensadores, não deveria se misturar aos assuntos políticos e ideológicos, com o risco de perder a pureza técnica que a faria funcionar adequadamente. Assim, segundo a retórica da burocra-tização, cada arena tem seu princípio e seu lugar na sociedade: assim como há um local para a política, deve haver uma região em que esta não tenha entrada permitida, pois a política é atividade de profissionais, e não de técnicos. É a utopia burocrática (ver Paiva, 2004a, 2004b).

Essa falsa divisão do trabalho, entre os motivados pelas paixões da ideologia e aqueles movidos pela razão técnica, realiza-se de 
maneira não muito uniforme no país. Fez-se mais presente, naturalmente, nas regiões de maior visibilidade e peso econômico, político e social. No Nordeste do país, por exemplo, o processo de modernização fora muito lento, e até mesmo inexistente em determinadas regiões, se comparado aos estados do Centro-sul do país. Assim foi nas regiões do estado de São Paulo e do Distrito Federal, respectivamente as duas maiores economias do país, que a modernização não só transformou a estrutura urbana das cidades, com as conhecidas reformas de urbanização implementadas nos grandes centros, mas significou também mudanças de comportamento, de papéis sociais, nas relações dos indivíduos entre si e com as instituições do Estado, sobretudo no âmbito do que chamei de contexto 2 , isto é, a partir do período pós-Vargas.

Assim, é razoável supor que o impacto dessa transformação se deu, na verdade, de maneira regionalmente diferenciada. Ou seja, realizou-se de acordo com o papel que cada região ocupou no cenário político e social, no momento da instituição do Estado getulista e nos períodos subseqüentes. Trata-se de um momento-chave, pois representa a criação de um aparato de Estado até então inexistente e desconhecido em nosso país, um Estado que, ao ser instalado, não é posto em um vazio, pois encontra em cada região uma estrutura política e um aparato burocrático muito distinto.

Assim, é possível compreendermos a força e os desafios impostos aos Centros de Saúde no estado de São Paulo. Os centros, como unidades político-administrativas, estavam historicamente em sintonia com um modelo burocrático calcado em certa descentralização administrativa e sanitária. No entanto, o interventor Ademar de Barros, como se sabe, embora não tenha sido exatamente fiel representante das propostas do Estado getulista na região, também não representou algo inteiramente avesso à política nacional imposta pela ditadura. Médico de formação, Ademar de Barros administrou São Paulo durante boa parte do Estado Novo - justamente a etapa mais duramente centralizadora-, ao longo do período 1938-1941, e à sua maneira imprimiu rumo próprio à administração local, embora em sintonia com os fins do governo autoritário. No campo da saúde pública, segundo Merhy (1992, p. 180), o interventor federal, que apoiou os Centros de Saúde, propôs uma supervisão das atividades, especializada por tarefas, casando-se assim à concepção que promulgava a necessidade de uma estrutura burocrática e administrativa geral, centrada em um modelo organizacional que propunha radical divisão de tarefas e especialização de funções, defendido, por organismos centralizadores como o Departamento de Administração do Serviço Público - Dasp.

E o mais importante, isso tudo sem romper, ao menos oficial ou formalmente, com o governo federal. A despeito da intenção de 
Vargas com respeito à criação, não só em São Paulo, como em todo o país, de uma estrutura administrativa não completamente permeável aos interesses imediatos dos chefes locais, isso foi em muitos sentidos posto por terra em São Paulo, graças, em boa medida, ao modelo de administração pública elaborado por Ademar de Barros. Com sua ascensão, em 1938, o interventor imediatamente destituiu diversos prefeitos paulistas, e os substituiu por membros do velho Partido Republicano Paulista - PRP. Dessa forma, em São Paulo, com Ademar de Barros, em comparação com a política geral do Estado Novo, ocorreu maior descentralização e, com isso, maior autonomia local, o que, em confronto com o Rio de Janeiro, favoreceu não só os policy-makers, mas também seus executores.

Assim Samuel Pessoa assume, em dezembro de 1942, o cargo de diretor geral do Departamento de Saúde do Estado de São Paulo (atual Secretaria de Saúde), até fevereiro de 1944. Durante esse curto período, buscou ali operar importante descentralização política nas atividades administrativas e nas políticas sanitárias do estado. Descentralização que, como já mencionei, não encontrava sintonia com a política do governo federal, sobretudo durante o período do Estado Novo. O passo mais decisivo, nesse sentido, foi a elaboração do Decreto 13.439, de 30 de junho de 1943, que cria onze delegacias de saúde, nas quais, segundo Merhy (1992, p. 180), atuavam inspetores técnicos que procuraram iniciar forte descentralização nessa rede de postos.

No entanto, apesar de alguma resistência à centralização promovida pelos organismos do governo federal, São Paulo não permaneceu imune ao ímpeto burocratizante característico do período, de acordo com a noção que discuti em trabalho anterior (Paiva, 2004b), a qual diferencia '(des)centralização' de 'burocratização'. Nas palavras de Merhy:

alguns estados, como São Paulo, ainda guardavam um fôlego autonomista pouco maior que os outros. Entretanto, no auge do Estado Novo até 1942 vê-se também neste estado a presença dos setores federais, como é o caso das reformas burocráticoadministrativas do sistema de contratação do funcionalismo público, e o caso da organização das estruturas de serviços que passaram a obedecer ao mesmo esquema organizacional e organogramático do governo federal. Desenvolveu-se uma valorização da figura do burocrata público de perfil técnico. (1992, p. 193)

O discurso de Pessoa, proferido por ocasião da formatura da turma do curso médico, em 1940, constitui documento extraordinário nesse sentido, pois nele o médico consegue condensar seu pensamento acerca dos grandes problemas e desafios da época no campo da saúde pública. Não só temas, como a centralização política, são ali abordados, mas também o saneamento do sertão, a 
administração pública de forma geral e a formação médica estão presentes de maneira muito contundente, o que custou a Pessoa de imediato ameaça de prisão pela polícia do interventor Ademar de Barros, insatisfeito com o quadro um tanto caótico que o médico desenhou para o estado. Penso que esse documento, publicado na Revista de Medicina, é tão importante e revelador a respeito da postura de Pessoa e de sua visão de mundo, que passarei a comentá-lo nas passagens a seguir.

Apesar da ocasião, uma formatura, o documento não traz exatamente um discurso comemorativo. $\mathrm{O}$ tom e a narrativa seguem um ritmo frenético de fatos e casos chocantes, que provocam no leitor, tal como originalmente no ouvinte, uma sensação de culpa diante de um quadro social considerado desolador. Trata-se, nesse ponto de vista, de um manifesto em que o médico convida os colegas recém-formados à 'ação', convoca-os a se comportarem como verdadeiros atores políticos em um processo de formação da nacionalidade, como ele mesmo considerou no documento. O discurso, publicado em doze páginas, de imediato informa a que veio, nas palavras de Pessoa:

Se entretanto, fosse praxe o dar-se título a discursos de paraninfo, desejaria que este se denominasse - 'sobre a necessidade de médicos rurais para o Brasil' ou então 'sobre a necessidade urgente de assistência médica e higiênica às populações rurais brasileiras'. E, antes de tudo, assistência aos nossos sertanejos, aos pioneiros das zonas novas, aos penetradores das matas e desbravadores da Natureza... (“Discurso proferido...", Pessoa, 1941, p. 11)

A princípio, a alusão "aos pioneiros das terras novas" parece indicar uma redução do campo de ação da atividade médica, circunscrita ao universo geográfico da 'marcha para Oeste', ou seja, à região marcada pelo vazio demográfico a que se refere Cassiano Ricardo (1959). No entanto, ao longo do documento, no qual também se incluem referências a ícones do movimento sanitarista dos anos 20, como Miguel Pereira, Pessoa deixa claro que se trata antes da "redenção do grande pecado da geração passada - o abandono das nossas populações rurais" (ibidem, p. 12).

O médico faz menção a uma estrutura agrária, de distribuição de terra e acesso a ela, extremamente insalubre, pois estimularia, a seu ver, a criação de comunidades completamente desestruturadas, do ponto de vista de infra-estrutura básica necessária para a instalação das pessoas. Seu argumento principal é desdobrado em dois pontos: o primeiro se refere à existência de escolas com crianças doentes, sem condições de aprendizagem, juntamente com professores ignorantes a respeito de cuidados básicos de saúde pública e tratamento das doenças endêmicas na região. Para esse ponto, sua 
sugestão é a criação de cursos que possam oferecer formação básica nessa matéria às professoras já instaladas nas comunidades, pois o médico prontamente reconhece a dificuldade de os profissionais dos grandes centros residirem em lugares, a bem da verdade, com péssimas condições de habitação e trabalho. Essa proposta, vale registrar, fazia parte do campo de práticas do pessoal do Serviço Especial de Saúde Pública, o Sesp.

O outro ponto abordado, diretamente vinculado ao argumento geral, diz respeito à estrutura e à organização da família. No ponto de vista de Pessoa, o estado de miséria permanente era o grande responsável pelo alto índice de mortalidade infantil na região; em média, segundo ele, cerca de 30 por cento das crianças morriam nos primeiros anos de idade, nas regiões de pobreza. De acordo com a proposta do médico, não somente as professoras teriam acesso ao conhecimento considerado básico a respeito da saúde e higiene, como também os pais, que assim poderiam zelar com mais cuidado pela saúde de seus filhos. Tudo isso aliado, é claro, à melhoria das condições materiais de existência das comunidades assoladas pelas doenças do sertão, com salários mais justos e melhor distribuição de renda.

A fim de melhor ilustrar sua proposta, e talvez afastar uma visão fatalista a respeito da 'natureza' nos trópicos, Pessoa aborda comparativamente a instalação de diferentes comunidades no hinterland brasileiro: de um lado, apresenta os grupos nacionais; de outro, os estrangeiros. Enquanto estes gozavam de condições infinitamente superiores em qualidade de vida, os nacionais subsistiam sob condições miseráveis de abandono e doenças. A explicação de Pessoa aponta, de um lado, a pequena força das autoridades do Estado diante dos poderosos fazendeiros que fechavam as portas de suas propriedades diante de medidas importantes de promoção à saúde das populações rurais; de outro, e em sintonia com o primeiro ponto, a própria mentalidade particularista dos proprietários, daninha aos interesses gerais da população e da nação.

Não havia, segundo Pessoa, nada congênito nos grupos nacionais que os vinculasse a uma vida repleta de doenças, ao passo que os estrangeiros estariam destinados à vida saudável e vigorosa, semente do progresso. A questão passava pela necessidade de melhor organização da estrutura do Estado, para que este pudesse intervir em um quadro próximo da anarquia política, marcado pelos interesses locais, avessos aos "interesses nacionais". Se em uma comunidade de colonos japoneses, prossegue o médico, "o serviço de combate à malária por mim mesmo orientado durante quatro anos, e custeado pelos japoneses, fez baixar este índice a 0,5 por cento o que, praticamente, fez desaparecer o perigo para a colonização", nas comunidades estritamente nacionais tudo se daria de forma diferente, como denunciado em seu discurso: 
E os proprietários dos patrimônios nacionais? Um deles nos negou total e absoluta licença para instalarmos um posto de tratamento de úlcera de Bauru, em sua propriedade, onde existem $20 \%$ de leishmanióticos. O pretexto para a recusa foi que um dispensário ali instalado traria má fama para o patrimônio. (Ibidem, p. 17)

Do ponto de vista administrativo, Pessoa considerou que a estrutura de intervenção no quadro social anteriormente apontado não era a mais conveniente, pois, em suas palavras, tal estrutura confiaria "exclusivamente ao Posto de Higiene ou Centro de Saúde a luta contra as moléstias predominantes nestas zonas" (ibidem, p. 18). Aqui, o médico antecipa a discussão que desenvolveria nos jornais de grande circulação, em meados dos anos 40, comentada anteriormente. Trata-se, em resumo, do que considerou como o divórcio entre as práticas do hospital e da saúde pública, o que tem muito a ver com o que assinalara como a necessidade de desenvolver "a mentalidade preventiva nos estudantes", uma mentalidade, podese dizer, mais sanitária e solidária. A respeito, o médico conclui:

Estou mesmo com os que acham que os nossos médicos recémformados deveriam passar alguns meses no sertão, a fim de se porem a par das necessidades médicas e mesmo sociais de nossos sertanejos. (Ibidem, p. 19)

As últimas palavras do discurso de Samuel Pessoa, retóricas ou não, não podem deixar de ser aqui reproduzidas, exatamente porque dizem muito a respeito da natureza do discurso dos médicos da década de 1920. Ao se dirigir aos formandos, o médico conclama: "sede a mais eficiente, a mais poderosa e a maior das forças sociais, para a saúde e redenção do Brasil" (ibidem, p. 20). Ao trazer à tona o papel primário da saúde na formação e constituição da nacionalidade brasileira, Pessoa se aproxima muito do fórum de preocupações em que, a bem da verdade, tal papel foi originado. Nessa ótica, a promoção da saúde não constitui somente, quero insistir, um direito, vazio de conteúdo, previsto em lei; aqui essa promoção está carregada por princípios que não só dizem respeito ao objeto da intervenção, o doente, mas também de maneira muito decisiva, têm a ver com aqueles que tratam dos males, isto é, os próprios médicos. Trata-se de um movimento histórico, no qual estão envolvidas pessoas, em um sentido eminentemente coletivo.

Em seu discurso de inauguração das novas instalações do Serviço de Profilaxia da Malária, em 1943, Pessoa volta a essa discussão, ressaltando seu desdobramento político-administrativo, do ponto de vista das políticas sanitárias. Em pleno Estado Novo, o médico critica o sentido das reformas administrativas responsáveis, segundo seu julgamento, pela separação radical entre as unidades 
administrativas e técnicas do serviço. Separação que se pretendia superar justamente com a inauguração do novo prédio e maior unificação das decisões e serviços. Em suas palavras, "a centralização nos proporciona ainda a possibilidade de melhor entrosamento" (“Discurso de inauguração...", Pessoa, 1943, p. 6).

A primeira impressão que tenho, ao observar tantos discursos ora a favor da centralização crescente e vigente, ora pela descentralização do universo das decisões, é de que se tratava realmente de um debate mal resolvido na época. Não posso afirmar que havia uma polarização bem definida a respeito do tema, pois na verdade, reconhecia-se que um ou outro sistema, quando levado ao extremo, produziria sempre distorções negativas para o encaminhamento das políticas públicas. O curioso é notar, no entanto, que poucos, e em poucas vezes, perceberam que, a despeito da necessidade de encontrar uma fórmula adequada para o antagonismo, o que constituía de fato um dilema, havia o fenômeno da burocratização, que imprimia novas regras de funcionamento do Estado. Isso se deu primeiramente em um sentido mais óbvio, porque institucional, ligado às reformas administrativas; e em outro sentido, decorrente do anterior, relacionado à entrada de novos atores sociais e sua contribuição para o processo de mudança administrativa que tornava mais complexo justamente o processo de decisões (Graham, 1968; Wahrlich, 1983; Bendix, 1996; Paiva, 2004a, 2004b).

Pessoa algumas vezes refere-se a um processo difuso, como veremos mais adiante, ligado à queda do idealismo dos médicos recémformados e dos formados a partir dos anos 40. Essa matéria, em sua opinião, tem muito a ver com certos problemas do ensino e da formação do médico, não mais tomados pelas questões sanitárias e, para usar uma expressão sua, não mais sintonizados com questões do patriotismo. Outras vezes, como já vimos, Pessoa faz menção ao problema de gestão no setor, ligado a um sistema administrativo que permitia e expressava uma divisão equivocada entre os diversos campos da medicina, tanto do ponto de vista dos saberes médicos, como do ponto de vista do pessoal técnico e administrativo.

Sem dúvida, todo o universo crítico de Pessoa está vinculado à sua visão de mundo e à sua formação intelectual. Nesse campo é explícita sua visão messiânica da profissão médica, tomada pela ideologia de salvação e construção nacional da saúde pública, elaborada nas primeiras décadas do século XX. No entanto, em sua obra, absolutamente pautada em novos critérios de se fazer ciência, o plano ideológico não se encontra desvinculado, ao contrário, serve ainda de mola mestra em todas as suas elaborações intelectuais, como veremos.

Pessoa publica, em 1946, sua Parasitologia médica, obra que permaneceu em circulação no meio acadêmico brasileiro, segundo Rey (2001, p.3), até, mais ou menos, o final da década de 1980, tamanha 
a importância do livro na área. Além dessa, considerada a sua mais importante obra, publicou Leishmaniose tegumentar americana e Problemas brasileiros de higiene rural, respectivamente em 1948 e 1949, trabalhos também de grande relevância. A produção acadêmica de Pessoa é invejável, mesmo para os padrões atuais. Produziu, segundo Luiz Hildebrando Pereira da Silva (2001, p. 8), 352 trabalhos científicos, mais de cinqüenta artigos em jornais e periódicos, nove livros e monografias, entre os quais os aqui destacados.

Problemas brasileiros de higiene rural foi encaminhado para a avaliação da congregação da faculdade, a 6 de setembro de 1948, como atesta carta assinada pelo próprio Samuel Pessoa, endereçada ao diretor da Faculdade de Medicina, doutor Renato Locchi. ${ }^{20} \mathrm{O}$ parecer favorável à publicação, assinado pelos doutores Eurico da Silva Bastos e F. Moura Campos foi encaminhado ao diretor, em 24 de setembro daquele ano. ${ }^{21}$ Foi Pessoa quem ficou diretamente responsável por uma espécie de processo de licitação, a fim de escolher a editora responsável pela publicação do trabalho então aprovado. ${ }^{22}$ No documento, o médico apresenta as razões que justificaram sua escolha, ao considerar que a Editora Progresso Nacional S.A. ofereceria maiores vantagens não à sua pessoa, mas à instituição. Em suas palavras:

pode-se desde logo ver a grande vantagem desta última proposta, pois posto livro à venda a Reitoria ou a faculdade no fim de tempo relativamente curto receberiam todo o capital emprestado, representando assim a edição do meu livro simples adiantamento de dinheiro. ${ }^{23}$

Aprovada a publicação de Problemas brasileiros de higiene rural, o diretor da faculdade, Renato Locchi, envia carta ao reitor da Universidade de São Paulo, Linneu Prestes, considerando que todo o processo tinha sido injusto e prejudicial ao autor. Em suas palavras:

Pela carta do Sr. Prof. Samuel Pessoa, V. Excia. poderá verificar que esse professor, pela proposta mais favorável, irá conseguir para si a irrisória importância de Cr \$ 12.000,00 (doze mil cruzeiros) com a publicação de seu trabalho que tanto tempo e esforço lhe custou.

Não parece justo que assim seja, porquanto compete à universidade acoroçoar a execução dos trabalhos didáticos a fim de formar a sua biblioteca universitária própria em benefício de seus inúmeros alunos, e isso só será possível com um amparo eficiente aos respectivos autores. ${ }^{24}$

Venho propor neste trabalho que a ação de médicos como Samuel Pessoa não é alimentada pela chama estéril da obrigação meramente utilitária ou técnico-profissional. Há algo mais, disseminado em 
suas ações e presente na própria identidade dos atores sociais, não revelado pela imagem do cidadão-profissional. Nuno Ramos, neto de Samuel Pessoa, ao comentar sua relação com o avô no ambiente doméstico, revela em alguma medida as idéias que moviam o velho médico. Em suas palavras:

e toda forma, a política era o pano de fundo diário daquela casa, numa proporção difícil de imaginar hoje em dia. Não podíamos deixar comida no prato porque havia crianças passando fome; não se abastecia o carro em outro posto que não a Petrobrás; o jardim estava repleto de árvores brasileiras (pau-brasil, pauferro, pitangueira etc.); depois do parabéns a você tradicional, tradução do happy birthday to you norte-americano, cantávamos uma outra melodia, parecida com uma valsa, autenticamente brasileira. (Ramos, 2001, p. 15)

Trata-se de indivíduo cujo padrão de comportamento mantém forte relação com os assuntos de ordem coletiva, especialmente aqueles tidos como nacionais. Ser bem-sucedido nesse campo dizia respeito à relação que se esperava estabelecer com as pessoas, sobretudo aquelas que se encontravam em condições de vida consideradas aviltantes. Essa postura pública não pode ser apreendida em expressões como 'romântico', como hoje muitos a encarceram, ou mesmo em considerações de juízo de valor, tais como 'bom caráter' ou 'mau caráter'. Na verdade comportamentos egoístas ou altruístas têm a ver menos com os indivíduos afetados, e mais com a estrutura social de seu tempo, pois esses padrões não são construídos no vazio, e sim por meio de mecanismos estritamente subjetivos, inseparáveis das condições de seu tempo.

Tais padrões dizem respeito, no final das contas, aos anseios de uma época. Do ponto de vista da psicologia social, em certo sentido, podemos considerar que pensar em si próprio, naquele tempo, dizia respeito à trajetória das massas, pois a auto-realização individual muitas vezes encontrava seu terreno mais fértil quando a pessoa era capaz de perceber como positiva sua contribuição e realização em um quadro mais geral, então denominado nacional. Não dizia respeito, normalmente, à capacidade do indivíduo para acumular riquezas e capitais. Para muitos, esse não era um fim em si mesmo. Para outros de nosso tempo, por sua vez, tornou-se mola-mestra.

Assim, a partir da aparentemente prematura saída de Samuel Pessoa da Faculdade de Medicina de São Paulo, aposentado em 1956, o médico inicia um período bastante fértil de incursões pelo país. Ofereceu cursos de graduação e pós-graduação, organizou laboratórios e centros de pesquisas nos estados de Alagoas, Sergipe, Paraná, Santa Catarina, Bahia, Goiás, Paraíba, Pará e Minas Gerais, até meados dos anos 70 (Silva, 2001, p. 7), tendo então recebido vários títulos de professor honoris causa das respectivas universidades. 
Essa prática quase nômade de muitos cientistas brasileiros tem muito a ver com os ideais que os faziam operar. Isso porque a medicina até então conservava dimensão fortemente territorial, de ocupação e de encaminhamento do processo civilizador, em sentido muito próximo do apontado por Norbert Elias (1994), herança dos médicos dos anos 20. Nesse caso, a medicina era menos uma profissão liberal, no sentido que lhe atribuímos hoje, e mais uma atitude de vida eminentemente pública, calcada na idéia ora de criação de uma realidade brasileira, ora de transformação do real considerado patológico.

A partir daí, seria ingênuo considerar que Samuel Pessoa, ou ainda os profissionais sob o mesmo padrão de comportamento, encaravam aqui e ali suas atividades, de maneira estritamente circunscrita às suas regiões geográficas ou a seus estados federais. Dá-se o contrário. De uma maneira geral os médicos pensavam a todo momento o Brasil, e não questões setoriais, de forma limitada e desprendida de um cenário nacional. Portanto, todo esse fermento ideológico é inseparável da força do nacionalismo, pois constitui sua própria substância.

O foco de Samuel Pessoa, de um ponto de vista bastante amplo, projetava-se em dois sentidos interligados: (1) o primeiro era a idéia da importância da saúde pública e do saneamento como filão de construção de uma gente saudável e em condições de se apresentar como cidadãos de uma nação moderna, característica mais elementar do movimento sanitário dos anos 20; (2) o outro ponto era o investimento na formação de quadros de cientistas especializados, em sintonia com as práticas da ciência moderna, isto é, profissionais pagos pelo Estado, com dedicação exclusiva ao mundo das descobertas e pesquisas científicas, traço novo e característico do mundo intelectual a partir dos anos 20, prematuramente, como dissemos, em São Paulo.

Dentro do primeiro aspecto (1), sem perder de vista o segundo (2), Pessoa trabalhou intensamente no Nordeste brasileiro contra os problemas sanitários que atingiam em cheio as populações de diversos estados. ${ }^{25}$ Em sua perspectiva, o panorama um tanto desolador era proveniente de um quadro político, econômico e social bastante complexo, no qual a atuação da máquina política e burocrática federal se fazia necessária e importante em determinados contextos. Em suas palavras, a respeito da saúde pública na região Nordeste:

Considerando-se também a fraca arrecadação estadual daquelas unidades da federação, as lutas políticas que envolvem ali os departamentos estaduais de saúde, dificultando todas as medidas de caráter administrativo, verifica-se que, não fosse a orientação sólida e científica dos Serviços da Organização Sanitária Federal, a população daqueles estados estaria à mercê das mais terríveis endemias. ("Profilaxia rural...", 1949, p. 15) 
Sua outra frente de batalha, o segundo aspecto, fica patente na contribuição a sólidas carreiras científicas, como a do médico Frederico Simões Barbosa, formado aos 22 anos na Faculdade de Medicina de Recife, em 1938, décadas depois seria renomado nas áreas da parasitologia, medicina tropical e epidemiologia. Em depoimento aos Cadernos de saúde pública (1997), Barbosa deixa claro o contexto responsável pela instituição de um ambiente acadêmico voltado para pesquisa em sua região. Em suas palavras:

contávamos com poucos recursos e não havia um ambiente acadêmico propriamente dito. Tampouco havia estímulos para que se seguisse carreira científica. Comigo aconteceu um fato fortuito que marcou minha vida. Foi a vinda de Samuel Pessoa a Recife para ministrar um curso de parasitologia médica. Isto aconteceu antes de eu me formar, em 1936. (p. 14, grifo meu)

Em última análise, não creio que o fato fosse tão 'fortuito', como o considerou Barbosa em seu depoimento. Pois aquele encontro com o mito fundador de uma tradição científica em parasitologia em Pernambuco, no final das contas não representou uma ação elaborada no âmbito estritamente individual, pois estava em sintonia com o amplo movimento histórico que atingia a medicina brasileira desde o início do século XX e, mais fortemente, no contexto do auge do movimento sanitário dos anos 20. Trata-se de um movimento de longa data, que já dava sinais de declínio, segundo o próprio Pessoa. Por exemplo, em sua conferência intitulada "A verdadeira universidade", na Salvador de 1962, são apontados diversos elementos que concorreram, a meu ver, para certa esterilização da saúde pública a partir da segunda metade do século $X X$. Um dos pontos explorados pelo médico, em suas palavras, reside no fato de que:

a riqueza, a industrialização, a ânsia de ganhar dinheiro, contaminaram de tal modo a mocidade, que todos se atiram à carreira clínica ou cirúrgica, pois ninguém está disposto a viver com ordenados medíocres, na esperança de realizar alguma descoberta.... ${ }^{26}$

Além disso, Pessoa também salienta o excesso de especialização como responsável, paradoxalmente, por certo empobrecimento intelectual do cientista, ao enclausurá-lo em uma área restrita do conhecimento humano, desconectando-o assim de um universo mais amplo de questões relacionadas ao seu objeto de estudo. No campo médico, isto se operaria com certa radicalização, segundo propõe Pessoa, com a separação dos fenômenos biológicos em relação aos sociais. 


\section{O médico 'subversivo': o contexto do pós-guerra}

O fim do primeiro período Vargas (1930-1945) não assinalou mudanças brutais, do ponto de vista da implementação de uma estrutura burocrática no país, embora o ritmo de burocratização já não fosse tão intenso, se comparado aos primeiros anos das reformas administrativas que mudaram em muito a face do Estado, a partir do início da década de 1930. Ocorre, contudo, importante diminuição do caráter centralizador do governo federal sobre os estados, justamente com o fim do Estado Novo (1937-1945). Assim, a queda de Getúlio Vargas, em 1945, não só põe fim ao longo período de forte intervenção do Estado nos assuntos locais, como também resulta em novo ordenamento político-administrativo nacional, que procurou aliar o poder e a burocracia ao novo perfil mais descentralizado da política brasileira. Novas instituições são criadas, incluindo-se aí os partidos políticos que terão atuação marcante durante todo o período conhecido como democrático, que se estende até o início dos anos 60 .

O rumo ideológico da sociedade brasileira é também outro, pois o nível de polarização entre os diversos segmentos sociais e políticos chega a patamares extraordinários. É o quadro internacional da Guerra Fria, em que figuraram globalmente como principais atores os norte-americanos versus os soviéticos. Eric Hobsbawm ${ }^{27}$ resume muito bem o espírito dessa nova etapa das políticas internacionais irradiadas por Washington e pelo Kremlin, presente na preocupação dos vencedores com os planos de recuperação dos vencidos, que poderiam, segundo alguns analistas da época, se reverter a favor do inimigo ideológico, seja ele ocidental (EUA) ou oriental (URSS).

O resultado foi que a tolerância aos comunistas no mundo ocidental, sob a esfera de influência política e econômica dos norteamericanos, tornou-se mínima, com a instauração de verdadeiras patrulhas ideológicas, que miravam não só as macropolíticas nacionais, como foi o caso do Chile, mas também a atuação de grupos considerados, sob essa ótica, subversivos, embora sem hegemonia política nacional, como era o caso dos comunistas no Brasil. Assim, todos considerados formalmente, governo ou oposição, foram alvo de uma estrutura política e policial extraordinariamente repressiva, que não só se utilizou da lei (ou de sua alteração), como também de mecanismos extremamente cruéis, como a perseguição política e social, a tortura e os assassinatos.

É curioso observar que Pessoa, não obstante sua formação acadêmica e profissional, inseparável da experiência da Fundação Rockefeller no estado de São Paulo, muda sensivelmente o tom de seu discurso com relação aos norte-americanos, ao considerar que: 
O ideal para o imperialismo norte-americano ... seria transformar o estudante brasileiro em um 'técnico', desligado do mundo em que vive, tal como se passa com o estudante norte-americano. (Palestra no Hospital das Clínicas da Faculdade de Medicina da Universidade Federal da Bahia, em 22.5.1962, citada em Pessoa, 1978, p. 272)

Aqui o contexto é outro. A leitura de todo o desenvolvimento técnico e burocrático que contextualizou a relação com os norteamericanos - estes, como se sabe, os principais irradiadores das idéias das reformas administrativas desde o período Vargas - passa a ser interpretada como manobra política de combate às ideologias, sobretudo aquelas ligadas ao campo da esquerda. Assim, Samuel Pessoa, que fez parte dos quadros do Partido Comunista Brasileiro - PCB, chegando a ser candidato a deputado no ano de 1945, também se transforma como ator social, pois novas ideologias vão compor seu padrão de comportamento, de acordo com a imagem capitalismo versus comunismo.

No entanto, é certo que não só o indivíduo se transforma, pois surge mesmo um novo tempo. Nesse sentido, o arquivo da Fundação Rockefeller possui documentos ${ }^{28}$ bastante sintéticos a respeito da trajetória dos cientistas que foram seus bolsistas. A trajetória de Pessoa até 1956 é exemplar, do ponto de vista de seu aproveitamento e de sua evolução profissional, exclusivas categorias consideradas para o quadro de análise da instituição, antes da instauração da Guerra Fria. Mesmo em momentos de grande acirramento ideológico da história brasileira, como aqueles marcados pelos acontecimentos de 1935 e 1937, a Fundação não exerceu função de patrulhamento ideológico, não pautando assim a avaliação da qualidade de seus quadros de bolsistas por (de)méritos extracientíficos (Castro Santos, 2001, p. IX-XIII).

No Pós-Guerra, os critérios são outros. Em documento da Fundação, datado de 24 de maio de 1956, considerou-se que Samuel Pessoa "tem sido influenciado por anos de treinamento não só em parasitologia, mas em atividades políticas subversivas". Em documento produzido no dia 25 de junho do mesmo ano, considerou-se que o médico brasileiro, ao viajar em comissão de estudos para a China, teria assim "prostituído sua incontestável habilidade científica como parasitologista".${ }^{29}$ Certamente são outros os parâmetros que se inauguram e têm relação com o novo ambiente ideológico e político que toma vulto a partir do final da Segunda Guerra Mundial.

No âmbito da política brasileira, não seria o ponto culminante da patrulha e perseguição ideológica. Esse ponto somente ocorre com todo o processo de cassação produzido pelos Atos Adicionais do regime militar, a partir da década de 1960, quando quase todo o Departamento de Parasitologia montado por Pessoa é esvaziado. ${ }^{30}$ Aqueles que até então eram seus assistentes de pesquisa foram 
obrigados a fugir da repressão, o que dispensa maiores comentários. Victor e Ruth Nussenzveig foram para a Universidade de Nova York, Luiz Hildebrando Pereira da Silva foi para o Instituto Pasteur de Paris, Leônidas e Maria Deane partiram para a Faculdade de Medicina de Valência, na Venezuela; Luiz Rey foi para o Instituto Politécnico Nacional, no México e, após breve retorno ao país, instalou-se por fim na sede da Organização Mundial da Saúde, em Genebra; além de outros tantos pesquisadores que arrumaram subitamente suas malas e partiram para diversos cantos do planeta.

A lista dos discípulos de Pessoa é grande, e tem relação com o estabelecimento de uma verdadeira ponte-aérea, patrocinada por Assis Chateaubriand, entre Recife e São Paulo, quando médicos recém-formados vieram trabalhar na Faculdade de Medicina e Cirurgia de São Paulo. Nomes como Lobato Paraense, Durval Lucena, J. O. Coutinho e Simões Barbosa, entre outros que, depois da experiência naquele estado, se espalharam por todo o país, levando adiante muito do projeto do velho mestre, como anteriormente explicitado por Simões Barbosa, responsável pela formação de muitos parasitologistas no Nordeste do Brasil.

Nesse período, caracterizado pela ditadura militar, Samuel Pessoa se refugia no Instituto Butantan, onde se dedica ao estudo dos trypanosomas, hemogragarinas, parasitas de cobras e lagartos. Sem abandonar a produção de trabalhos acadêmicos e, principalmente, sem deixar de enxergar, por meio da ciência, uma possibilidade de melhorar as condições de vida da população do país. Em suas palavras:

afastado desde 1964 de minhas lidas científicas preferenciais, que sempre foram o estudo da epidemiologia e profilaxia das doenças parasitárias no hinterland de nossa pátria, encontrei abrigo e possibilidades de estudar nos queridos Instituto Butantan e Adolfo Lutz. No primeiro tenho-me dedicado ao estudo de hemoparasitos de serpentes e de outros répteis e no segundo dos parasitos de mamíferos silvestres. (Conferência na Sessão Inaugural do IV Congresso Médico do Oeste Paulista, em 10.9.1975, citada em Pessoa, 1978, p. 228)

Lá, como tenho encontrado nas fontes da época, ao contrário do que possa parecer à primeira vista, o médico manteve suas preocupações com relação às questões fundamentais para a saúde pública no país. Seus estudos sobre os hemoparasitas dos ofídios tinham relação com a idéia de encontrar uma vacina contra a leishmaniose, já que os parasitos que atingem as cobras são da mesma família que os que atingem os seres humanos, e com a transmissão por mosquitos.

Assim, a despeito da sensível ruptura em sua trajetória, resultante de sua transferência para o Instituto Butantan, Pessoa continua situado nas velhas discussões da saúde pública em que foi 
formado, pautando seu tempo e dedicação àqueles assuntos ligados às grandes epidemias que atingiam, sobretudo, a gente do interior do país. É Luiz Hildebrando quem descreve, com dramaticidade e realismo, as condições que provavelmente concorreram para o falecimento do mestre, no ano de 1976. Em suas palavras: "Pessoa faleceu em setembro de 1976, um ano depois que esbirros da polícia o levaram encapuzado até o reduto da Oban, na rua Tutóia de São Paulo, onde foi submetido, aos 77 anos de idade, a severo interrogatório" (2001, p. 9). É com a institucionalização do regime militar em nosso país, e com todas as conseqüências políticas decorrentes da intervenção dos técnicos-burocratas, também no setor da saúde, que coincidentemente, ou não, personagens como Samuel Pessoa começaram a nos deixar, para que de maneira majoritária entrasse em cena, gradualmente, aquele profissional estritamente prestador de serviços, cuja marca da carreira bem-sucedida passa, muitas vezes, pelo sucesso financeiro e econômico. Todos aqueles ideais de salvação e construção nacional pela saúde pública, bem como o sanitarismo, simultaneamente como arena de conflitos e bandeira de identificação da classe médica, começam a cair, como se diz, em desuso.

\section{Considerações finais}

Meu esforço foi tentar demonstrar que a trajetória de Samuel Pessoa, embora regionalmente marcada por novos 'elementos', típicos dos novos tempos que se inauguram a partir da década de 1930, é inseparável do difuso universo ideológico que formou a elite médica brasileira durante a Primeira República. Um universo marcado por discursos e práticas nacionalistas algumas vezes desencontrados e, por isso, difíceis de serem definidos conceitualmente em poucas palavras. Em síntese, trata-se de um ambiente de discussão em que o papel da saúde esteve sempre em primeiro plano, como alavanca que permitiria finalmente erguer o país de uma condição subalterna no cenário internacional para uma condição mais privilegiada, típica de uma nação moderna. ${ }^{31}$

Além disso, não quero apenas sustentar como tese um continuísmo qualquer, marcado pela presença desses ideais - provenientes dos anos 20 - nos anos a partir de 1930, como sobreviventes da revolução que inaugura novo período político na história de nosso país. Trata-se, sobretudo, de compreender as dificuldades operacionais que esses ideais tiveram que enfrentar justamente na nova era, a era da burocracia.

Nesse sentido, creio que a trajetória de Samuel Pessoa constitui excelente exemplo, ao demonstrar exatamente os desafios de fazer circular a ideologia pela rotina de um mundo em crescente burocratização.

Um mundo, curiosamente, cuja criação teve no médico um dos atores sociais mais importantes, mas deixou de contar com sua parti- 
cipação integral em algumas de suas esferas, sobretudo naquela ligada à estrutura político-administrativa, em pleno processo de mudança sob o regime de Vargas.

É um novo tempo, porque a burocratização não significa estritamente apenas mera transformação na estrutura de administração do Estado, embora também o fosse. Foi uma nova era, porque mexeu também com o plano das relações humanas, tanto interpessoais como institucionais. Não representou, nesse sentido, simples fenômeno político, como sugere a expressão 'centralização política', pois foi além, ao atravessar o plano de relações das pessoas que geriam a máquina pública, e seus recursos, tanto de materiais como de pessoal.

A trajetória de Samuel Pessoa assinala os dilemas desse novo tempo, pois seus princípios não estavam em sintonia com essa lógica crescentemente burocrática, que ele mesmo não consegue compreender claramente. Como muitos de sua época, o médico reduziu os desafios político-administrativos à questão da centralização versus descentralização. Como filho de um tempo ido, Pessoa não parece perceber plenamente que o acesso aos fóruns de decisão do Estado não passava mais exclusivamente pelo âmbito das relações pessoais, em que essencialmente fora formado.

Nesse ponto, a crescente especialização burocrática, tão mal compreendida, do ponto de vista dos seus efeitos, por muitos contemporâneos, significou que o sucesso do indivíduo dependia de sua capacidade de ser extremamente habilidoso socialmente (como também politicamente), a ponto de levar adiante seus projetos e propostas por canais de estrutura crescentemente impessoal, ainda que os próprios caminhos estritamente burocráticos não se encontrassem regularmente formados. Não havia uma burocracia constituída, como salientam os teóricos da burocracia em países subdesenvolvidos, de acordo com os moldes mais próximos do tipo-ideal weberiano.

Esse sistema, por assim dizer, híbrido - isto é, nem cravado no patrimonialismo aristocrático dos anos 20 , nem na rotina burocrática stricto sensu -, significou que homens tomados pelo universo ideológico das primeiras décadas do século passado não dispunham facilmente de terreno favorável a seus princípios mais fundamentais, justamente aqueles firmados por um nacionalismo difuso, impregnado pelo sanitarismo (como movimento social e político).

De certo modo, para Pessoa a problemática foi dupla, já que ele enfrentava problemas no encaminhamento de propostas de políticas públicas de saúde, por falta de suporte institucional; de outro modo, Pessoa carecia também de uma estrutura burocrática eficiente, que amparasse a criação de uma estrutura de investimento e fomento da pesquisa científica no país, tarefa a que bem ou mal se dedicou, de maneira, como vimos, marcadamente messiânica. 
O resultado foi que, ao estar a meio caminho de um processo histórico, Pessoa já não dispunha integralmente do modelo aristocrático que regeu a sociedade e o Estado brasileiros durante a Primeira República, e arregimentou muitas das propostas do sanitarismo "pelo alto" (Castro Santos, 1993), mas também não podia usufruir uma estrutura burocrática eficiente o bastante que pudesse ampará-lo, com segurança, rumo à institucionalização da carreira científica no país, de acordo com os padrões europeus e, sobretudo, norte-americanos.

Esse aparente 'vácuo histórico' representou, em termos práticos, algumas dificuldades em sua trajetória não só profissional, mas também pessoal. Sua ação - sua motivação primeira - situava-se, como dissemos, mais além de uma lógica ou ética profissional, pois dizia respeito à sua conduta pessoal, à sua maneira de viver, e dava assim sentido à sua existência. Pessoa, como muitos de sua geração, enfrentou os desafios de seu tempo, imprimindo ao longo de sua trajetória respostas muitas vezes autênticas aos desafios encontrados, em embate quase existencial, pois tinha relação, por tudo que já se disse, também com a identidade do sujeito atuante.

Assim, a sua aparente cegueira, e de muitos daquela época, com relação ao que substancialmente se passava na sociedade e no Estado brasileiros era na verdade um ingrediente estrutural do processo. Representava a porta de entrada do conturbado século XX, quando inumeráveis mudanças políticas e econômicas não se fizeram acompanhar, no mesmo compasso, por mudanças nas estruturas mentais, como diziam alguns pensadores da época. ${ }^{32} \mathrm{~A}$ estrutura política, econômica e social não mais parecia responder aos anseios práticos dos atores sociais, pois muitos ainda se miravam, consciente ou inconscientemente, em um modelo que já não existia integralmente, sobretudo no plano formal. É o desencontro do homem com o seu tempo.

\section{NOTAS}

${ }^{1}$ Sobre a atuação da Fundação Rockefeller no Brasil, ver os trabalhos de Luiz Antônio de Castro Santos (1987; 1993), Lina Rodrigues de Faria (1994; 2002) e Castro Santos \& Faria (2003).

2 No quadro do acordo entre a Fundação Rockefeller e o governo de São Paulo, Samuel Darling veio em 1918 para organizar um laboratório de higiene no estado. No entanto, adoece e retorna aos Estados Unidos em 1920, sendo substituído por seu assistente, o médico Wilson Smillie.

${ }^{3} \mathrm{O}$ quenopódio era droga, na época, utilizada no mundo todo para o combate à ancilostomíase. Em conferência realizada no Hospital das Clínicas, em Salvador, no ano de 1962, o médico comentou a dificuldade de encontrar a substância no país, pois, para fazer sua pesquisa, fora obrigado a comprá-la de firma inglesa, encarregada de conseguir o produto nos laboratórios estrangeiros (ver Pessoa, 1962). Além disso, sua dosagem e posologia não eram suficientemente conhecidas, o que resultava freqüentemente em vítimas, até mesmo fatais, com o uso do produto.

4 Segundo Jaime Benchimol, apesar do desenvolvimento inegável da microbiologia no Rio de Janeiro, especialmente com as atividades do Instituto Soroterápico de Manguinhos (a futura Fiocruz), "na realidade, foi em São Paulo que se fundou, em 1892, a primeira instituição voltada para a aplicação sistemática da microbiologia à saúde pública" (1990, p. 15), com a criação do Instituto Bacteriológico, organizado por Adolfo Lutz, o qual curiosamente, aos olhos da reforma Paula Souza, seria instituição secundária, como mostra Ribeiro (1993). 
${ }^{5}$ De acordo com a autora, São Paulo foi o estado que recebeu maior apoio financeiro da Fundação, ao passo que Bahia e Pernambuco, com altíssimos índices de contaminação por ancilostomíase, febre amarela e malária, não foram sequer contemplados no orçamento da instituição. Isso de deveu, segundo a autora, a uma avaliação prévia da Fundação sobre as condições locais cujos investimentos e recursos poderiam produzir maior impacto positivo.

${ }^{6}$ Segundo documento oficial da Fundação Rockefeller, Samuel Pessoa foi indicado para o cargo em 4 de abril de 1922. (Biography files, Rockefeller Archive Center, NY/Arquivo Fundação Rockefeller, IMS/Uerj.)

7 Dr. Boyd era chefe da Seção de Malária da Comissão.

${ }^{8}$ Carta para Samuel Pessoa, enviada em 19.5.1922 e assinada por L. W. Hackett, diretor da Fundação Rockefeller no Brasil, comenta a recusa do médico em trabalhar com o Dr. Boyd, mas não o censura; ao contrário, reafirma que os "postos estão sempre abertos" para o médico. (Ver Memorial apresentado à congregação da Faculdade de Medicina de São Paulo, [1930/1931]).

${ }^{9}$ Na ocasião da morte de Milward, em 1932, Pessoa proferiu discurso na Faculdade de Medicina em homenagem ao ex-professor, publicado sob o título "Discurso em memória ao professor Guilherme" (Pessoa, 1932).

${ }^{10}$ Labra, a meu ver, muito claramente segue um modelo de análise que percebe a burocratização da sociedade como um fenômeno homogêneo, imposto por intervenção estrangeira, com data marcada, como se vê na passagem a seguir: "independente do contexto histórico, político, cultural ou geográfico de que se trate, a conexão sanitária internacional vai justamente envidar todos seus esforços para infundir a idéia de que a organização e a administração, cientificamente fundamentais e tecnicamente orientadas da saúde pública, poderão levar, por outro lado, a racionalização da execução das decisões adotadas na incontrolável esfera política dos países tropicais..." (1985, p. 385).

11 Lina Faria (2003) sugere em sua pesquisa que não só o Brasil recebe influência da Rockefeller, com seus novos padrões científicos, como também a própria Rockefeller (eu diria alguns personagens da instituição) se vê obrigada a rever seus princípios teóricos, tradicionalmente eugênicos, relativos à saúde pública, ao adotar, segundo documento citado pela autora, uma visão calcada na idéia da miscigenação como possibilidade de surgimento de 'colonos fortes'.

12 Segundo Faria (2003), antes de 1930 o Distrito Federal tinha quatro centros de saúde, e durante o primeiro período Vargas foram construídos mais doze. Já São Paulo, que teve o primeiro Centro de Saúde do país, em 1925, na década de 1940 tinha sete centros.

${ }^{13}$ Assim, apesar de os Centros de Saúde representarem, do ponto de vista administrativo, um modelo sem afinidade com o padrão verticalizador, não exerciam, de um ponto de vista mais amplo, segundo Pessoa, sua função horizontal adequadamente, por conta da baixa integração entre os serviços e atividades.

14 Conforme demonstrou Lawrence Graham (1968, p. 38-61), esse modelo surgiu nos Estados Unidos, e teve forte impacto no Brasil, sobretudo a partir do pós-guerra. Sua proposta central reside na idéia de que o ser humano pode e deve ter uma orientação científica calcada nas noções de economia e eficiência como metas de organização. Ao propor esse modelo, seus teóricos não consideraram o comportamento humano como variável a ser levada em conta no ambiente de trabalho, pois o compreendem como entidade eminentemente passiva.

${ }^{15}$ De acordo com Amílcar V. Martins, antes da produção intelectual de Pessoa, os professores liam o Traité de parasitologie, de Émile Brumpt, como também Clinical parasitology, de Craig \& Faust.

16 O DENERu foi criado em 1956, nos primeiros anos de atuação do Ministério da Saúde, a fim de combater as endemias de Doença de Chagas, malária, tracoma e esquistossomose, via promoção de educação sanitária à população rural. Sua estrutura administrativa foi desenvolvida a partir dos antigos serviços de malária, peste e febre amarela. Segundo Rezende \& Heller (2002, p. 196-7), a criação do DENERu provocou conflitos deste órgão com o DNS, que viu seu poder de intervenção diminuído, ao ser transformado em aparelho normativo.

17 Em depoimento: "passei um ano na Europa com uma bolsa da antiga Liga das Nações, onde me dediquei ao estudo da malária na Itália e na Iugoslávia, sendo que após fiz o curso de Medicina Tropical no célebre Instituto de Hamburgo e, finalmente, passei alguns meses em Paris, no laboratório de Parasitologia do maior parasitologista moderno, o professor Émile Brumpt". A esse professor, o médico substituiria na Faculdade em São Paulo, após a criação da cadeira de Parasitologia (Documento: Conferência de agradecimento ao título de professor honoris causa da Universidade Federal de Goiás, citado em Pessoa, 1978, p. 305). Encontram-se ainda publicados os comprovantes de seus cursos fora do país, em memorial organizado pelo próprio Samuel Pessoa [1930/ 1931].

18 “Quando, em 1931, fui nomeado, após concurso, para exercer o cargo de professor de parasitologia da Faculdade de Medicina de São Paulo, levei para aquela cadeira o gosto de pesquisa de campo e de estudos de epidemiologia das nossas principais endemias rurais." (Conferência de agradecimento ao título de professor honoris causa da Universidade Federal de Goiás, citado em Pessoa, 1978, p. 307.) 
19 Há, nesse sentido, na passagem da década de 1920 para a de 1930, vários elementos de continuidade histórica, como a continuação das campanhas sanitárias contra a febre amarela no governo Vargas, e mesmo o crescimento dos centros de saúde como modelo de atendimento médico.

20 Carta de Samuel Pessoa a Renato Locchi. São Paulo, 6.9.1948.

21 Parecer da comissão de avaliação para Renato Locchi. São Paulo, 24.9.1948.

22 Carta de Samuel Pessoa a Renato Locchi. São Paulo, 7.10.1948.

23 Carta de Samuel Pessoa a Renato Locchi. São Paulo, 7.10.1948, p. 2.

24 Carta de Renato Locchi a Linneu Prestes. São Paulo, 18.10.1948.

25 Em 1952, em colaboração com o MES, Pessoa organizou o Posto Experimental da Faculdade de Medicina de São Paulo, em Aracaju, para estudo de campo de esquistossomose; em 1954, o Departamento de Parasitologia da Faculdade de Medicina da Universidade da Paraíba, em João Pessoa; e em 1956, o Posto Experimental do DENERu, em Maceió, também para o estudo da esquistossomose.

26 Conferência realizada no IPIT, a 12.6.1962, publicada no mesmo ano pela Fundação Gonçalo Muniz.

27 Quem tiver interesse nas conseqüências políticas globais do final da Segunda Guerra Mundial e na subseqüente instauração da Guerra Fria poderá consultar o excelente livro de Eric Hobsbawm (1995); aqui vou apenas recuperar alguns aspectos que interessam diretamente ao nosso argumento.

28 Biography files, Rockefeller Archive Center, NY/Arquivo Fundação Rockefeller, IMS/Uerj.

29 Eis, nas palavras de Pessoa, o relatório que produziu mais descontentamento por parte dos norte-americanos: "A comissão científica internacional, da qual fizemos parte, após dois meses de estudos na Coréia e na China, demonstrou à sociedade, cientificamente, que os povos coreano e chinês foram vítimas de ataques microbiológicos repetidos por unidades dos Estados Unidos da América do Norte" (Atualidades médicas e biológicas, Rio de Janeiro, jun.-jul., 1953, citado em Pessoa, 1978, p. 322).

30 Em abril de 1964, o governador do estado de São Paulo, Ademar de Barros, em sintonia com o contexto de embate ideológico dos militares golpistas, expurgou vários funcionários da Universidade de São Paulo.

31 Assim, não cabe discutir se a saúde pública foi efetivamente mais eficiente, do ponto de vista do seu impacto no controle das doenças, durante a Primeira República, se comparada aos períodos posteriores.

32 Em estada na Polônia, em 1996, percebi o péssimo atendimento prestado por comerciários, na capital, Varsóvia. A explicação que me pareceu mais convincente à época foi que apesar da mudança na estrutura político-econômica no país, com a guinada rumo ao capitalismo, uma mudança no mesmo tom não se deu no plano das mentalidades, pois muitos funcionários privados ainda pareciam estar avessos à lógica do "cliente sempre tem razão", e tratavam os consumidores como se prestando algum favor, muito inspirados, segundo me disseram, em tempos já idos.

\section{REFERÊNCIAS BIBLIOGRÁFICAS}

\section{FONTES PRIMÁRIAS}

\section{A) DOCUMENTOS GERAIS}

Carta de Eurico da Silva São Paulo, 24.9.1948 (Pasta Samuel Pessoa, Museu Histórico da Bastos e F. A. Moura Faculdade de Medicina da Universidade do Estado de São Paulo).

Campos para Renato Locchi

Carta de Renato Locchi para Linneu Prestes

Carta de Samuel Pessoa para Renato Locchi

Carta de Samuel Pessoa para Renato Locchi.

Carta de Samuel Pessoa para Renato Locchi

São Paulo, 18.10.1948 (Pasta Samuel Pessoa, Museu Histórico da Faculdade de Medicina da Universidade do Estado de São Paulo).

São Paulo, 17.7.1941 (Pasta Samuel Pessoa, Museu Histórico da Faculdade de Medicina da Universidade do Estado de São Paulo).

São Paulo, 6.9.1948 (Pasta Samuel Pessoa, Museu Histórico da Faculdade de Medicina da Universidade do Estado de São Paulo).

São Paulo, 7.10.1948 (Pasta Samuel Pessoa, Museu Histórico da Faculdade de Medicina da Universidade do Estado de São Paulo). 
Cópia dos documentos comprobatórios de experiência profissional de Samuel Pessoa publicados em conjunto com o Memorial apresentado à Congregação da Faculdade de Medicina de São Paulo por Samuel Pessoa para o concurso para a cadeira de parasitologia. São Paulo: Estabelecimento Gráfico Irmãos Ferraz, [1930/1931]. (Biblioteca da Faculdade de Medicina da Universidade de São Paulo).

Discurso de Carlos da Silva Lacaz professado na Faculdade de Medicina da Universidade de São Paulo por ocasião da morte de Samuel Pessoa. São Paulo, 4.9.1976 (Pasta Samuel Pessoa, Museu Histórico da Faculdade de Medicina da Universidade do Estado de São Paulo).

Discurso proferido pelo Prof. Samuel Pessoa ao paraninfar os doutorandos de 1940. Separata da Revista de Medicina. São Paulo, jan.1941, v. 41.

Fichas pessoais de Samuel B. Pessoa. (Biography files. Rockefeller Archive Center, NY/Arquivo da Fundação Rockefeller, IMS-Uerj).

Homenagem da Faculdade de Medicina da Universidade de São Paulo para Samuel Pessoa, assinada por Carlos da Silva Lacaz. São Paulo, 31.5.1977, 9 p. (Pasta Samuel Pessoa, Museu Histórico da Faculdade de Medicina da Universidade do Estado de São Paulo).

Homenagem do XIII Congresso da Sociedade Brasileira de Medicina Tropical e do II Congresso da Sociedade Brasileira de Parasitologia para Samuel Pessoa. 5 p. (Pasta Samuel Pessoa, Museu Histórico da Faculdade de Medicina da Universidade do Estado de São Paulo).

Memorial apresentado à Congregação da Faculdade de Medicina de São Paulo por Samuel Pessoa para o concurso para a cadeira de parasitologia. São Paulo: Estabelecimento Gráfico Irmãos Ferraz, [1930/1931]. (Biblioteca da Faculdade de Medicina da Universidade de São Paulo).

Parecer de avaliação para publicação, assinado por Eurico da Silva Bastos e F. A. Moura Campos para Renato Locchi. São Paulo, 24.9.1948 (Pasta Samuel Pessoa, Museu Histórico da Faculdade de Medicina da Universidade do Estado de São Paulo).

\section{B) ARTIGOS NA IMPRENSA}

Pessoa, Samuel 1945

Pessoa, Samue 1968

Pessoa, Samuel 1944

Pessoa, Samuel 1945

Pessoa Samuel 1945

Pessoa, Samuel 1945

Pessoa, Samue 1932

Pessoa, Samue 1943
Uma grande campanha sanitária.

Folha da Manhã, São Paulo, 20.dez., ano XXI, n. 6667, p. 6.

Do que morre o Brasil.

Realidade, São Paulo, ano 2, n. 22, jan., p. 104-9.

A profilaxia rural no Nordeste do Brasil.

O Estado de S. Paulo, ano LXX, n. 22, p. 15.

Os hospitais e a saúde pública.

Folha da Manhã, São Paulo, 11.out., ano XXI, n. 6609, p. 6.

Malária crônica.

Folha de S. Paulo, 21.set., ano XXI, n. 6592, p. 6.

A amebíase.

Folha da Manhã, São Paulo, 2.ago., ano XXI, n. 6550.

Discurso em memória do professor Guilherme.

O Estado de S. Paulo, 19.nov., ano LVIII, n. 9343, p. 3.

Discurso de inauguração do novo prédio.

O Estado de S. Paulo, 6.jun., ano LXIX, n. 22.621, p. 6. 
"Prof. Samuel Pessoa" (obituário) 1976

“Dr. Samuel Barnsley Pessoa” (obituário) 1976

"Prof. Samuel Pessoa (entrevista com o prof. Pessoa)"

$$
1955
$$

\section{C) OBRAS}

Pessoa, Samuel B. 1978

Pessoa, Samuel B. 1967

Pessoa, Samuel B. 1962a

Pessoa, Samuel B. $1962 b$

\section{BIBLIOGRAFIA}

Benchimol, Jaime Larry (coord.)

1990

Benchimol, Jaime Larry;

Teixeira, L. Antônio 1993

Bendix, Reinhard 1996

Castro Santos, L. A. 2001

Castro Santos, L. A. 1993

Castro Santos, L.A. 1987

Castro Santos, L. A. 1985

Castro Santos, L. A.; Faria, Lina R. de 2003

Coimbra Jr., Carlos E. A. 1997

Elias, Norbert 1994
Folha de S. Paulo, 4.set.

Revista Saúde, São Paulo, out., p. 8.

O Bisturi, São Paulo, set., ano XXII, n. 72, p. 5.

Ensaios médico-sociais

2. ed. São Paulo: Cebes/Hucitec.

Parasitologia médica.

Rio de Janeiro: Guanabara Koogan.

A pesquisa na saúde pública.

Salvador (BA): Fundação Gonçalo Moniz.

A verdadeira universidade.

Salvador (BA): Fundação Gonçalo Moniz.

Manguinhos do sonho à vida: a ciência na Belle Époque.

Rio de Janeiro: COC/Fiocruz.

Cobras, lagartos e outros bichos: uma história comparada dos Institutos Oswaldo Cruz e Butantan. Rio de Janeiro: Ed. UFRJ.

Autoridade administrativa no Estado-nação. In: Construção nacional e cidadania. Estudos de nossa ordem social em mudança. Trad. Mary Amazonas Leite de Barros. São Paulo: Ed. UFSCAR. p. 139-78. (Clássicos, 5)

Bandeirantes e pioneiros da ciência no Brasil. In; Marinho, Maria Gabriela Silva Martins da Cunha. Norte-americanos no Brasil: uma história da Fundação Rockefeller na Universidade de São Paulo (1934-1952). Campinas (SP): Autores Associados/Universidade São Francisco. v. 1, p. 210.

A reforma sanitária Pelo Alto: o pioneirismo paulista no início do século XX. Dados. Revista de Ciências Sociais, v. 36, n. 3.

Power, ideology, and public health in Brazil, 1889-1930. Tese de doutoramento em sociologia. Cambridge, Mass., Harvard University.

O pensamento sanitarista na República Velha: uma ideologia de construção da nacionalidade. Dados. Revista de Ciências Sociais, v. 28, n. 2.

A reforma sanitária no Brasil: ecos da Primeira República.

Bragança Paulista (SP): Edusf.

Uma conversa com Frederico Simões Barbosa. Cadernos de saúde pública, Rio de Janeiro: Fiocruz, v. 13, n. 1, p. 145-55, jan.-mar.

O processo civilizador. Uma história dos costumes.

(v. 1) Trad. Ruy Jungmann. Rio de Janeiro: Jorge Zahar. 
Faria, Lina R. de 2003

Faria, Lina R. de 2002

Faria, Lina R. de 1994

Fausto, Boris 2000

Graham, Lawrence S. 1968

Hobsbawm, Eric 1995

Hochman, Gilberto 1998

Labra, Maria Eliana 1985

Lessa, Renato

1999

Love, Joseph

1982

Merhy, Emerson E. 1991

Paiva, Carlos Henrique Assunção 2004a

Paiva, Carlos Henrique Assunção $2004 b$

Paiva, Carlos Henrique Assunção

Ramos, Nuno

2001

Reis, Elisa 1991

Rey, Luiz 2001

Rezende, Sonaly C.; Heller, Léo 2002
Ciência, ensino \& administração em saúde: a Fundação Rockefeller e a criação do Instituto de Higiene de São Paulo. Tese de doutoramento em Saúde Coletiva, IMS/Uerj, Rio de Janeiro.

A Fundação Rockefeller e os serviços de saúde em São Paulo (1920-30): perspectivas históricas. História, Ciências, Saúde-Manguinhos, v. 9, n. 3, p. 561-90, set.-dez.

A fase pioneira da reforma sanitária no Brasil: a atuação da Fundação Rockefeller (1915/1930). Dissertação de mestrado, Instituto de Medicina Social/Uerj, Rio de Janeiro.

História do Brasil.

8. ed. São Paulo: Fundação para o Desenvolvimento da Educação.

Civil service reform in Brazil: principles versus practice.

Austin: University of Texas Press.

Era dos extremos: o breve século XX (1914-1991).

Trad. Marcos Santarrita. São Paulo: Companhia das Letras.

A era do saneamento. As bases da política de saúde pública no Brasil. São Paulo: Hucitec/Anpocs.

O movimento sanitarista nos anos 20: da conexão sanitária internacional à especialização em saúde pública no Brasil. Dissertação de mestrado em Administração Pública, Escola Brasileira de Administração Pública/FGV, Rio de Janeiro.

A invenção da República. Campos Sales, as bases e a decadência da Primeira República Brasileira. Rio de Janeiro: Topbooks.

A locomotiva: São Paulo na federação brasileira (1889-1937).

Trad. Vera Alice Cardoso da Silva. Rio de Janeiro: Paz e Terra.

A saúde pública como política: um estudo de formuladores de políticas. São Paulo: Hucitec.

A utopia burocrática: um estudo histórico-comparativo das políticas públicas de saúde. Rio de Janeiro e São Paulo (1930/1960). Tese de doutoramento em Saúde Coletiva, IMS/Uerj, Rio de Janeiro.

Burocratização e modernização: proposição de uma distinção teóricoanalítica. Revista Espaço Acadêmico, Maringá (PR), n. 3, abr. Disponível em www.espaçoacademico.com.br.

A saúde pública em tempos de burocratização: o caso do médico Noel Nutels. História, Ciências e Saúde - Manguinhos, v. 10, n. 3, p. 827-51, set.-dez.

Fala, fala, fala, fala. In: Samuel Pessoa. Coleção Documentos, série especial Ciência e Tecnologia. São Paulo: Instituto de Estudos Avançados da Universidade de São Paulo, n. 1, p. 13-7, fev.

Poder privado e construção de estado sob a Primeira República. In: Boshi, Renato R. (org.) Corporativismo e desigualdade: a construção do espaço público no Brasil. Rio de Janeiro: Ed. Iuperj. p. 43-68.

Pessoa e seu tempo. In: Samuel Pessoa. Coleção Documentos, série especial Ciência e Tecnologia. São Paulo: Instituto de Estudos Avançados da Universidade de São Paulo, n. 1, p. 1-7, fev.

O saneamento no Brasil: políticas e interfaces. Belo Horizonte (MG): Ed. UFMG. 
Ribeiro, Maria Alice R.

1993

Ricardo, Cassiano

1959

Silva, Luiz Hildebrando

Pereira da

2001

Wahrlich, Beatriz

de Souza

1983

Weber, Max

de Souza

1970
História sem fim: inventário da Saúde Pública. São Paulo (1880-1930). São Paulo: Ed. Unesp.

Marcha para oeste: a influência da Bandeira na formação social e política do Brasil. 3. ed. Rio de Janeiro: J. Olympio.

O homem engajado. In: Samuel Pessoa. Coleção Documentos, série especial Ciência e Tecnologia. São Paulo: Instituto de Estudos Avançados da Universidade de São Paulo, n. 1, p. 7-12, fev.

Reforma administrativa na era Vargas.

Rio de Janeiro: Ed. Fundação Getúlio Vargas.

Ciência e política: duas vocações.

Trad. Leonidas Hegenberg e Octany Silveira da Mota. São Paulo: Cultrix.

Recebido para publicação em julho de 2004. Aprovado para publicação em setembro de 2006. 